\title{
Production and loss of high-density batholithic root, southern Sierra Nevada, California
}

\author{
Jason Saleeby \\ Division of Geological and Planetary Sciences, California Institute of Technology, Pasadena, California, USA
}

Mihai Ducea

Department of Geosciences, University of Arizona, Tucson, Arizona, USA

Diane Clemens-Knott

Department of Geological Sciences, California State University, Fullerton, California, USA

Received 20 February 2002; revised 21 March 2003; accepted 1 July 2003; published 18 November 2003.

[1] Eclogites are commonly believed to be highly susceptible to delamination and sinking into the mantle from lower crustal metamorphic environments. We discuss the production of a specific class of eclogitic rocks that formed in conjunction with the production of the Sierra Nevada batholith. These high-density eclogitic rocks, however, formed by crystal-liquid equilibria and thus contrast sharply in their petrogenesis and environment of formation from eclogite facies metamorphic rocks. Experimental studies show that when hydrous mafic to intermediate composition assemblages are melted in excess of $1 \mathrm{GPa}$, the derivative liquids are typical of Cordilleran-type batholith granitoids, and garnet + clinopyroxene, which is an eclogitic mineralogy, dominate the residue assemblage. Upper mantlelower crustal xenolith suites that were entrained in mid-Miocene volcanic centers erupted through the central Sierra Nevada batholith are dominated by such garnet clinopyroxenites, which are shown further by geochemical data to be petrogenetically related to the overlying batholith as its residue assemblage. Petrogenetic data on garnet pyroxenite and associated peridotite and granulite xenoliths, in conjunction with a southward deepening oblique crustal section and seismic data, form the basis for the synthesis of a primary lithospheric column for the Sierra Nevada batholith. Critical aspects of this column are the dominance of felsic batholithic rocks to between 35 and $40 \mathrm{~km}$ depths, a thick $(\sim 35 \mathrm{~km})$ underlying garnet clinopyroxenite residue sequence, and interlayered spinel and underlying garnet peridotite extending to $\sim 125 \mathrm{~km}$ depths. The peridotites appear to be the remnants of the mantle wedge from beneath the Sierran arc. The

Copyright 2003 by the American Geophysical Union. 0278-7407/03/2002TC001374 principal source for the batholith was a polygenetic hydrous mafic to intermediate composition lower crust dominated by mantle wedge-derived mafic intrusions. Genesis of the composite batholith over an $\sim 50$ m.y. time interval entailed the complete reconstitution of the Sierran lithosphere. Sierra Nevada batholith magmatism ended by $\sim 80 \mathrm{Ma}$ in conjunction with the onset of the Laramide orogeny, and subsequently, its underlying mantle lithosphere cooled conductively. In the southernmost Sierranorthern Mojave Desert region the subbatholith mantle lithosphere was mechanically delaminated by a shallow segment of the Laramide slab and was replaced by underthrust subduction accretion assemblages. Despite these Laramide events, the mantle lithosphere of the greater Sierra Nevada for the most part remained intact throughout much of Cenozoic time. A pronounced change in xenolith suites sampled by Pliocene-Quaternary lavas to garnet absent, spinel and plagioclase peridotites, whose thermobarometry define an asthenosphere adiabat, as well as seismic data, indicate that much of the remaining sub-Sierran lithosphere was removed in Late Miocene to Pliocene time. Such removal is suggested to have arisen from a convective instability related to high-magnitude extension in the adjacent Basin and Range province and to have worked in conjunction with the recent phase of Sierran uplift and a change in regional volcanism to more primitive compositions. In both the Mio-Pliocene and Late Cretaceous lithosphere removal events the base of the felsic batholith was the preferred locus of separation. INDEX TERMS: 1020 Geochemistry: Composition of the crust; 3640 Mineralogy and Petrology: Igneous petrology; 8110 Tectonophysics: Continental tectonics-general (0905); 8121 Tectonophysics: Dynamics, convection currents and mantle plumes; 8159 Tectonophysics: Rheology_crust and lithosphere; KEYWORDS: Sierra Nevada, batholith petrogenesis, delamination, eclogites. 
Citation: Saleeby, J., M. Ducea, and D. Clemens-Knott, Production and loss of high-density batholithic root, southern Sierra Nevada, California, Tectonics, 22(6), 1064, doi:10.1029/ 2002TC001374, 2003.

\section{Introduction}

[2] Over the past decade there has been an increase in awareness that during the formation of felsic magmatic arcs a substantial mass of olivine-poor, high-density residues should accumulate at depth. Key to this realization are melting experiments of hydrous mafic assemblages at pressures in excess of $\sim 1 \mathrm{GPa}$ which render tonalitic to granodioritic melts and garnet + clinopyroxene rich residue assemblages [Wolf and Wyllie, 1993, 1994; Rapp and Watson, 1995]. The likelihood that such melt-residue relations are a first-order process in magmatic arcs is supported by REE studies showing that felsic batholithic rocks are commonly in equilibrium with a garnet-rich residue [Dodge et al., 1986, 1988; Gromet and Silver, 1987; Ross, 1989; Ducea, 2001]. Such REE data have been interpreted to imply an eclogitic source for magmatic arcs. The "eclogitic" residue rock that we consider here is fundamentally different, however, having formed by crystal-liquid equilibria as opposed to solid state metamorphic reactions. In this paper we review evidence for the development of a thick $(\sim 35 \mathrm{~km})$ high-density root complex beneath the Cretaceous Sierra Nevada batholith [Ducea and Saleeby, 1998a; Ducea, 2001]. Such a high-density root complex contrasts markedly with the low-density crustal root originally envisaged for the batholith which was invoked as a mechanism to support the elevation of the modern Sierra Nevada [Bateman and Eaton, 1967], but which has since been shown not to exist [Jones, 1987; Wernicke et al., 1996; Jones and Phinney, 1998; Ruppert et al., 1998; Fliedner et al., 2000]. The high-density root complex consists primarily of garnet and pyroxenes, mainly clinopyroxene. The Cretaceous Sierra Nevada batholith may be treated as the type Cordilleran batholithic belt, having formed along the North American plate edge during subduction of the Farallon plate. The resolution of this garnet pyroxenite root beneath the batholith carries important implications for the existence of similar roots beneath other major segments of the Cordilleran batholithic belt, and by analogy other Phanerozoic, and Phanerozoiclike, batholithic belts.

[3] The potential accumulation of substantial masses of garnet-clinopyroxene residues beneath magmatic arcs has led a number of workers to suggest that such lower-crustal cumulates ultimately sink into the mantle [Wolf and Wyllie, 1994; Rapp and Watson, 1995; Ducea and Saleeby, 1998b].
Recent analysis of subcontinental lithospheric mantle chemical structure and rheology suggests that in general Phanerozoic age lithosphere sections upon cooling to stable conductive geotherms will be gravitationally unstable relative to the asthenosphere, and will tend to sink or delaminate [O'Reilly et al., 2001]. The presence of a substantial thickness of garnet-clinopyroxene rocks within such lithosphere sections should add to their gravitational instability. In this paper we review evidence for the sinking of the sub-Sierran garnet pyroxenite complex and adjacent peridotitic lithosphere into the underlying mantle [Ducea and Saleeby, 1998b]. Based primarily on peridotite Re-Os isotopic data Lee at al. [2000, 2001] discuss the likelihood of delamination processes having affected the lithosphere beneath the Sierra Nevada. They did not consider the garnet pyroxenite complex in their analysis, considering it as "crustal rocks". Another aim of this paper is to clarify the definition of the lithosphere that evolved beneath the Sierra Nevada batholith, and to explore how its loss fits into the petrogenetic and tectonic development of the region. As we track the evolution of the sub-Sierran lithosphere it will become clear that it has changed dramatically through time.

[4] We pose the question that if the production and loss of garnet pyroxenite root complexes are a global process in arc evolution then perhaps this is an effective multistage mechanism for the fractionation and long-term isolation of felsic crust. This process may carry important implications for the long-term geochemical evolution of the mantle. Our findings further suggest that as the garnet pyroxenite complex sank into the mantle, large-ion lithophile element-rich accessory phases melted and supplied enriched silicic veins to asthenospheric peridotites which appear to have ascended and replaced the complex [Ducea and Saleeby, 1998c]. This provides a mechanism for reenriching at least the shallow mantle in such elements through geologic time.

[5] The central and southern Sierra Nevada batholith have offered a rich array of findings by virtue of superimposed latest Cretaceous and Cenozoic processes. Regional tectonic events which disrupted the southernmost Sierran batholith in latest Cretaceous-Paleocene time (Laramide orogeny) resulted in an oblique crustal section which extends virtually to the base of the felsic batholith [Saleeby, 1990; Pickett and Saleeby, 1993; Malin et al., 1995; Saleeby, 2003]. Furthermore, mid-Miocene to Quaternary low-volume volcanic centers in the southern Sierra and adjacent Basin and Range province offer a time series in sampling of the sub-Sierran mantle by their accidental entrainment of lower crust and upper mantle xenoliths. Petrogenetic and age data on the oblique batholithic section and on the xenoliths, when integrated

Figure 1. (opposite) Map showing the general geology of the southern Sierra Nevada batholith and adjacent regions (compilation after Saleeby [1981, 1990]). Thermobarometric isopleths for depth of emplacement of the Cretaceous batholith are compiled from Ague and Brimhall [1988], Pickett and Saleeby [1993], Dixon [1995], and Ague [1997]. The structure of the Tehachapi-Rand deformation belt (TRDB) is generalized from Sharry [1981], Silver and Nourse [1986], Saleeby et al. [1987], Malin et al. [1995], and Wood and Saleeby [1998]. Locations of late Cenozoic volcanic-hosted xenolith sites are after Ducea and Saleeby [1996] and Ducea [1998]. 





with geophysical data, lead us to a three-dimensional view of the Sierra Nevada and its mantle underpinnings and how they evolved over the past $\sim 100$ m.y.

\section{Sierra Nevada Batholith in Three Dimensions}

[6] Our discussion focuses on the southern half of the Sierra Nevada batholith, whose geomorphic expression is truncated in the south by the Neogene Garlock fault (Figure 1). This sinistral fault developed preferentially along the Late Cretaceous-Paleocene Tehachapi-Rand deformation belt, a complex structural system which is directly linked to the depth of exposure of the southernmost Sierran Nevada batholith [Malin et al., 1995; Saleeby, 2003]. Igneous barometry [Ague and Brimhall, 1988], the preservation of mid-Cretaceous suprabatholithic silicic volcanic complexes [Saleeby et al., 1990; Fiske and Tobisch, 1994], and the presence of Early Cretaceous ring dike complexes [Clemens-Knott and Saleeby, 1999] indicate shallow levels of exposure for the batholith between latitudes $38^{\circ}$ and $36^{\circ}$ $\mathrm{N}$. To the south there is a southward steepening gradient in depth of exposure to $\sim 1 \mathrm{GPa}$ depths in the western Tehachapi Range [Pickett and Saleeby, 1993; Ague, 1997]. This gradient is offset along the axis of the southernmost Sierra by the Late Cretaceous proto-Kern Canyon fault (Figure 1). However, structural continuity between the shallow and deep level exposures is preserved along the regional strike of the batholith, which renders an oblique crustal section [Saleeby, 1990]. The principal tilt direction for the oblique section is approximated by the Figure 6 section line shown on Figure 1. Figure 6 is discussed in depth below.

[7] The Cretaceous Sierra Nevada batholith was generated and emplaced into a metamorphic framework that possessed a suture between Paleozoic oceanic lithosphere to the west and North American Proterozoic lithosphere to the east [Saleeby, 1981, 1990; Kistler, 1990]. The derivative suture belt remained active as a lithospheric boundary through the end of the Jurassic. Opinions differ as to whether the suture belt represents principally collisional or transform tectonics. For the purpose of our focus, however, the important point is that a long-active lithospheric boundary ceased as such, and became "welded" into the metamorphic framework of the Cretaceous batholith. Correspondingly, batholith petrochemical patterns show generation of the western domains of the batholith primarily within a depleted mantle (oceanic) regime, and axial to eastern domains within a continental lithospheric domain [Kistler and Peterman, 1973; DePaolo, 1981; Saleeby et al., 1987; Kistler, 1990; Chen and Tilton, 1991; Clemens-Knott et al., 1991; Coleman et al., 1992; Pickett and Saleeby, 1994; Sisson et al., 1996]. The lithologic expression of this transverse compositional gradient is a western batholith domain rich in mafic and tonalitic rocks, and an eastern domain predominately granodioritic in composition [Moore, 1959; Saleeby, 1981, 1990; Clemens-Knott, 1992]. The Sierra Nevada batholith also displays a pronounced transverse age gradient with mafic magmatism commencing $\sim 130 \mathrm{Ma}$ in the west and felsic magmatism ending in the east by $\sim 80$ Ma [Evernden and Kistler, 1970; Saleeby and Sharp, 1980; Stern et al., 1981; Chen and Moore, 1982; Saleeby et al., 1987, 1990]. During this 50 m.y. history of batholith generation, the greatest volume of material was emplaced between 100 and $84 \mathrm{Ma}$. The batholith also contains Jurassic and Triassic plutons along its northwest and southeast margins. These lower-volume plutons are separated in time from the Cretaceous composite batholith by regional suture belt deformations and a magmatic lull [Saleeby, 1981], and thus for the purpose of this paper are treated as part of the prebatholithic metamorphic framework.

[8] There are three key features of the depth and compositional zonation patterns discussed above that are pertinent to our focus.

[9] 1. Direct observations of the oblique crustal section indicate that the axial and eastern domains of the batholith are predominantly felsic to depths corresponding to $\sim 1 \mathrm{GPa}$ pressure. These observations are consistent with seismic refraction data across shallower-level exposures (0.1 to $0.3 \mathrm{GPa}$ ) of the batholith to the north which show low velocities characteristic of felsic crust extending down to 30-35 km (Moho) depths [Jones and Phinney, 1998; Ruppert et al., 1998; Fliedner et al., 2000].

[10] 2. Observations in the deep-level exposures show that hydrous cumulates ranging from ultramafic to quartz dioritic compositions underwent local partial remelting to yield tonalitic leucosomes and garnet rich residues. Such remelting is constrained by age data to have occurred within the same mid-Cretaceous batholith growth cycle in which the cumulates formed [Saleeby et al., 1987; Pickett and Saleeby, 1994; R.W. Kistler, written communication, 1997].

[11] 3. Mafic batholith rocks of Cretaceous age not only constitute a significant proportion of the western batholith domain, but they are also widespread as subordinate members of the eastern felsic batholith domain [Saleeby, 1981; Coleman et al., 1992; Sisson et al., 1996; Coleman and Glazner, 1998]. This is taken to indicate that the production of basaltic magmas in the mantle beneath the batholith was an integral part of batholith magmatism. We will return to these features in the synthesis of a primary lithospheric column for the Sierra Nevada below.

\section{Age and Petrogenetic Settings of Volcanic-Hosted Xenoliths}

[12] Volcanic-hosted xenoliths of the southern Sierra region fall into two age/compositional suites as differentiated on Figure 1 [after Domenick et al., 1983; Dodge et al., 1986, 1988; Mukhopadhyay and Manton, 1994; Beard and Glazner, 1995; Ducea and Saleeby, 1996, 1998a, 1998b; Ducea, 1998; Lee et al., 2000, 2001]. The first group is from Miocene volcanic centers bracketed to between 12 and $8 \mathrm{Ma}$ in eruptive age (late Middle to early Late Miocene). These are referred to as the mid-Miocene suite which is characterized by abundant garnet pyroxenites, garnet-bearing and spinel-bearing peridotites, and mafic granulites. The second suite is from Pliocene-Quaternary volcanic centers; 




Figure 2. Pressure-temperature (P-T) diagram with thermobarometric results summarized for late Cenozoic volcanic hosted xenolith suites from the southern Sierra Nevada region [after Mukhopadhyay and Manton, 1994; Ducea and Saleeby, 1996; Ducea, 1998; Lee et al., 2000, 2001]. Also shown are selected phase boundaries and solidi for hydrous mafic and ultramafic assemblages [after Basaltic Volcanism Study Project, 1981; Wolf and Wyllie, 1993, 1994; Rapp and Watson, 1995; Vielzeuf and Schmidt, 2001]. (a) Results from the mid-Miocene suite consisting of 18 garnet and spinel peridotites for high-T array, for which nine samples were also measured for orthopyroxene zonation patterns which define cooled array. Additionally, the two lowest-P spinel peridotites yield unique heating histories as well as isotopic signatures of subcontinental mantle lithosphere (SCML). Arrows simply link related data arrays and do not represent quantitative P-T trajectories. The garnet pyroxenite array is defined by 22 samples and the garnet granulite array by eight samples. The small triangle shows peak conditions measured for the deepest exposed levels of southern Sierra Nevada batholith [Pickett and Saleeby, 1993 ]. (b) Results from the Pliocene-Quaternary suite, for which 13 spinel and plagioclase peridotites lie along adiabat as shown and for which two samples disperse to lower-T conditions. For comparison, the final equilibrium field of the sub-Sierran batholith mantle lithosphere represented by the mid-Miocene suite is also shown. gt, garnet; hb, hornblende; pl, plagioclase; px, pyroxenites; sp, spinel.

it is devoid of garnet-bearing rock types, and is characterized by abundant spinel and plagioclase peridotites. The mid-Miocene xenolith localities are concentrated in areas characterized by relatively shallow-level exposures of the batholith, greater than $100 \mathrm{~km}$ north of the oblique crustal section. This indicates ascent through a relatively complete batholithic crustal column in a region that escaped the Laramide tectonics which rendered the deep batholithic exposures of the oblique crustal section. We will focus first on the mid-Miocene suite.

[13] The mid-Miocene suite of xenoliths is characterized by a wide compositional spectrum of rock types which formed under deep crust to upper mantle conditions. Garnet clinopyroxenites are the most abundant rock types, followed by garnet websterites, granulites and peridotites. Initial petrologic and geochemical studies focused primarily on granulitic and some pyroxenitic members of the suite, and concluded that the samples studied formed part of a lower-crustal mafic cumulate complex that formed in conjunction with the Sierra Nevada batholith [Domenick et al., 1983; Dodge et al., 1986, 1988; Clemens-Knott, 1996]. Mukhopadhyay and Manton [1994] worked on peridotites and pyroxenites from the suite, and related their petrogenesis to the evolution of the mantle wedge beneath the Sierra Nevada batholith. Geochronologic and additional petrogenetic data for the suite were integrated with these studies and interpreted further in the context of lower crust-upper mantle construction in conjunction with batholith production [Ducea, 1998, 2001; Ducea and Saleeby, 1998b]. Here we focus first on the granulites and garnet pyroxenites and their relation to the batholith.

[14] Age and petrogenetic data tie the granulites and garnet pyroxenites to the genesis of the Cretaceous batholith [Ducea and Saleeby, 1998a; Ducea, 2001]. Sm/Nd mineral 



Figure 3. Plots of modal proportions of residual assemblages produced by dehydration partial melting of a typical arc basalt with $1 \%$ water. The modal proportions of residues were calculated using the thermodynamic algorithm MELTS [Ghiorso and Sack, 1995]. Compositions suitable for Sierra Nevada felsic batholith were produced at melt fractions between 10 and 55\%. These results illustrate that the theoretically predicted assemblages are granulitic at $1 \mathrm{GPa}$ and garnet clinopyroxenite at $1.5 \mathrm{GPa}$.

isochron ages on garnet clinopyroxenites and garnet granulites fall uniquely within the range of $\mathrm{U} / \mathrm{Pb}$ zircon ages for the central and southern batholith. Time-corrected (100 Ma, median age for southern batholith) $\mathrm{Sr}, \mathrm{Nd}$ and $\mathrm{Pb}$ radiogenic isotopic ratios likewise cluster about the maxima for those determined for the central and southern batholith. Oxygen isotope data for batholithic rocks, garnet pyroxenites and granulites cluster together as well. Concentration data on REE for high-volume Sierran tonalites and granodiorites can be correlated to REE data for garnet clinopyroxenites by partition coefficients as complementary melt-residue assemblages. Such a melt-residue relationship is consistent with the experimental studies of Wolf and Wyllie [1993, 1994], Rapp and Watson [1995], and Vielzeuf and Schmidt [2001]. This can be visualized by considering thermobarometric data for the granulites and pyroxenites.

[15] Figure 2 summarizes thermobarometric data for both the mid-Miocene and Pliocene-Quaternary suites of xenoliths [after Mukhopadhyay and Manton, 1994; Ducea and Saleeby, 1996; Ducea, 1998; Lee et al., 2000, 2001]. We focus first on garnet pyroxenites and granulites of the midMiocene suite. P-T fields defined by data for these two rock types are outlined by bold lines on Figure $2 \mathrm{a}$. The garnet pyroxenite data cluster at pressures of 1.5 to $2.5 \mathrm{GPa}$ with outlier data points extending the field as appendage-like features to pressures as high as $3.3 \mathrm{GPa}$ and as low as $0.8 \mathrm{GPa}$. Granulites, typically containing garnet, cluster between 0.8 and $1.3 \mathrm{GPa}$, and overlap with the lowest pressure garnet pyroxenites as well as the peak P-T conditions determined near the base of the oblique crustal section (small dark triangle on Figure 2a). These data are interpreted here in the context of crystal-liquid equilibria. The wet basalt solidus is also plotted on Figure 2a [after Wolf and Wyllie, 1993, 1994; Vielzeuf and Schmidt, 2001]. The garnet pyroxenite data cluster along the liquid present side of the solidus above the plagioclase out boundary, and the granulites cluster between the plagioclase out boundary and the garnet in boundary. The lower bounds of the garnet pyroxenite data cluster along with the granulite data and appear to follow a reentrant that forms in the basalt solidus at decreasing water contents as shown by the 1 percent $\mathrm{H}_{2} \mathrm{O}$ solidus line on the inset of Figure $2 \mathrm{a}$.

[16] Considering the relationships between the thermobarometric data discussed above and the experimentally determined melting relations of hydrous basaltic systems; and considering the parallel and complimentary geochemical relationships between the xenoliths and the batholith that were discussed above, we assert that the P-T data on the garnet pyroxenite and granulite xenoliths to a first order reflects crystal-liquid equilibria in the source region of the batholith. This equilibria was characterized by the partial melting of hydrous mafic assemblages with the production and extraction of felsic melts, and the accumulation of garnet pyroxenite and lower-pressure granulite residues. The P-T relations for these xenoliths as well as the experimentally determined phase boundaries for wet basaltic systems shown on Figure $2 \mathrm{a}$ are consistent with thermodynamic modeling of the dehydration partial melting of a typical island arc basalt containing $1 \%$ water (Figure 3 ). In these models felsic melts with suitable compositions for the Sierra Nevada batholith are produced at melt fractions of between 10 and 55\%. As shown in the calculated modes on Figure 3, at $1 \mathrm{GPa}$ the residue assemblage is a garnet granulite, and at $1.5 \mathrm{GPa}$ the residue assemblage is a garnet clinopyroxenite.

[17] Peridotite xenoliths from the mid-Miocene suite are less abundant than garnet pyroxenites, and consist of garnet and spinel peridotites with pressures between $\sim 1.3$ and 4.2 GPa [Mukhopadhyay and Manton, 1994; Ducea and Saleeby, 1996; Ducea, 1998; Lee et al., 2000, 2001]. Many of the peridotites show evidence of decompression by the breakdown of garnet to spinel and/or other lower-grade mineral aggregates. Temperature determinations for the peridotites define a high- $T$ data cluster that lies along the wet peridotite solidus. A subset of these samples have been analyzed for orthopyroxene temperature zonation patterns which record cooling of $100^{\circ}-300^{\circ} \mathrm{C}$ in conjunction with or following decompression. Both the high-T and cooled data 
fields are shown on Figure 2a as the elongated shaded areas. Geochemical studies of these peridotites yield heterogeneous $\mathrm{Sr}, \mathrm{Nd}, \mathrm{Pb}$, and $\mathrm{Os}$ isotopic compositions [Mukhopadhyay and Manton, 1994; Lee et al., 2000, 2001; Zeng et al., 2001a]. Coupled Nd-Sr data show values lying on the asthenospheric mantle array, and a scatter of values suggesting a continental component. Os isotopic data likewise show asthenosphere affinities for a number of samples, as well as the introduction of continental components in some samples. The peridotites in general show variably high $\mathrm{Mg}$ numbers, and low $\mathrm{Na}$ and Ti clinopyroxene contents that are correlated to coexisting forsterite contents. These geochemical patterns suggest melt extraction events and variable degrees of depletion, which as discussed below, are considered to have occurred in the mantle wedge beneath the actively forming batholith. There is a second subordinate class of shallowlevel spinel peridotites that show evidence of heating from relatively low-T to high-T conditions. The P-T data for these samples are shown by the small shaded elliptical areas on Figure $2 \mathrm{a}$. In addition to the distinctive thermal history of this class of peridotites, these samples yield isotopic data suggesting derivation from North American subcontinental mantle lithosphere [Mukhopadhyay and Manton, 1994; Lee et al., 2000, 2001]. Thus the peridotite xenoliths from the mid-Miocene suite appear to define a stratified upper mantle with shallow remnants of subcontinental mantle lithosphere, and deeper asthenosphere-affinity material that locally incorporated continental components. The shallow lithosphere remnants were heated up to the conditions that existed at the granulite-garnet pyroxenite transition at $\sim 1.3 \mathrm{GPa}$. The deeper mantle peridotites were cooled from conditions that resemble the wet peridotite solidus over an $\sim 2.5 \mathrm{GPa}$ pressure range.

[18] The cooled peridotite P-T data array along with the garnet pyroxenite $\mathrm{P}-\mathrm{T}$ field are interpreted to approximate a lithospheric conductive geotherm that matured following the $\sim 80$ Ma cessation of Sierran batholithic magmatism (Figure 2b). Some of the orthopyroxene $\mathrm{T}$ zonation data from the cooled array have been modeled by Lee et al. [2000,2001] to have resulted from conductive cooling over an $\sim 50$ m.y. time interval in Late Cretaceous-early Cenozoic time. The apparent negative slope of the garnet pyroxenite data was suggested by Ducea and Saleeby [1996] to be an artifact of prolonged conductive cooling as well. However, the appendage-like features of the data array that define the negative slope (Figure 2a) could themselves be an artifact of the sparse data points at the high- and low-P extremes of the array. Orthopyroxene is rare or absent in most of the garnet pyroxenites, and thus $\mathrm{T}$ zonation data comparable to that for the peridotites is lacking. However, phase relations of the garnet pyroxenites suggest that many of the samples were also cooled perhaps as much as $200^{\circ} \mathrm{C}$ from their initial equilibration conditions. Many of these pyroxenites are bimineralic garnet and clinopyroxene. Hornblende is rare or absent in most samples. This indicates that most of the garnet pyroxenites initially equilibrated at temperatures that exceeded the hornblende out line, which is shown on the inset of Figure 2a. Most of the high and intermediate $\mathrm{P}$ garnet pyroxenites that lack hornblende lie as much as $200^{\circ} \mathrm{C}$ within the hornblende present field. This suggests cooling that is comparable to that of the orthopyroxene cooling profiles measured in the peridotites. We will return to the cooling history of the mid-Miocene xenolith suite in the context of the Laramide orogeny termination of Sierran arc activity below.

[19] We focus briefly here on the Pliocene-Quaternary suite of xenoliths. As noted above this suite is totally devoid of garnet-bearing rock types, thus making thermobarometric determinations more challenging and less precise. Nevertheless, phase relations between plagioclase and spinel peridotites coupled with the Ca-in-olivine barometer and pyroxene thermometry yield a P-T field (Figure 2b) for which most of the samples cluster along an asthenosphere adiabat with a potential temperature of $\sim 1180^{\circ} \mathrm{C}$ [Ducea and Saleeby, 1996]. As shown on Figure 2b, the P-T field for the Pliocene-Quaternary suite contrasts sharply from that of the mid-Miocene suite. We interpret the Pliocene-Quaternary suite as samples of modern asthenosphere that has replaced much of the subbatholith mantle lithosphere represented by the mid-Miocene suite [Ducea and Saleeby, 1998b]. As discussed below this replacement process occurred in Late Miocene-Pliocene time.

\section{A Primary Lithosphere Column for the Sierra Nevada Batholith}

[20] The P-T relations of Figure 2a along with the relative abundances of the xenoliths which constitute the mid-Miocene suite [Ducea and Saleeby, 1996; Ducea, 1998] define a vertical lithologic sequence consisting of basal garnet peridotite with inclusions of garnet pyroxenite, overlain by a garnet pyroxenite complex with inclusions of garnet and shallower spinel peridotite, in turn overlain by garnet granulites with inclusions of garnet pyroxenite. This sequence is integrated with geological relations of the oblique crustal section in the construction of a primary lithosphere column for the Sierra Nevada batholith (Figure 4). We have focused this column for rocks of the $\sim 100$ Ma time of batholith genesis. The map trace of the oblique crustal section is best defined by $\sim 100$ Ma batholithic rocks, and the most intact remnant of a suprabatholithic volcanic complex (Ritter Range caldera) is likewise $\sim 100 \mathrm{Ma}$ in age. Furthermore, $\mathrm{Sm} / \mathrm{Nd}$ mineral isochron ages for the garnet pyroxenite and garnet granulite xenoliths fall roughly around $100 \mathrm{Ma}$. The procedure used for the construction of the crustal part of the column was to use down structure viewing techniques along the trace of the Figure 6 section line (shown on Figure 1), which reaches subvolcanic levels at $\sim 0.2 \mathrm{GPa}$ conditions, and then cut and paste the structure of the Ritter Range area, as expressed down to $\sim 0.2 \mathrm{GPa}$ conditions, to the top of the column. The mantle lithosphere structure is more conjectural and is based on the lithologic sequence discussed above for the xenoliths.

[21] The Figure 4 reconstruction demonstrates the predominance of felsic batholithic rocks in the crustal column to $\sim 35 \mathrm{~km}$ depths. The direct observations that this recon- 


\section{CRUSTAL SECTION}

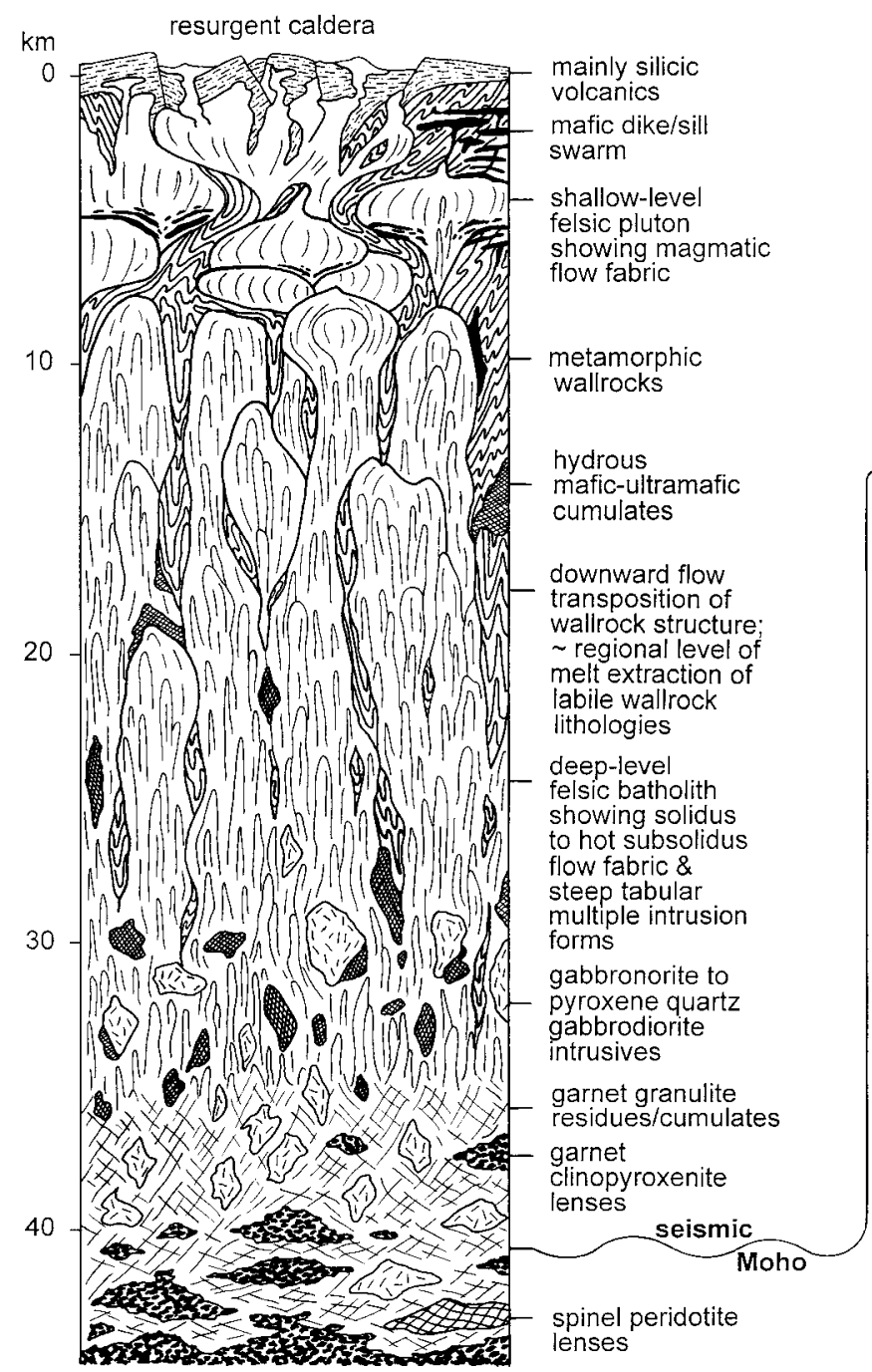

LITHOSPHERE SECTION

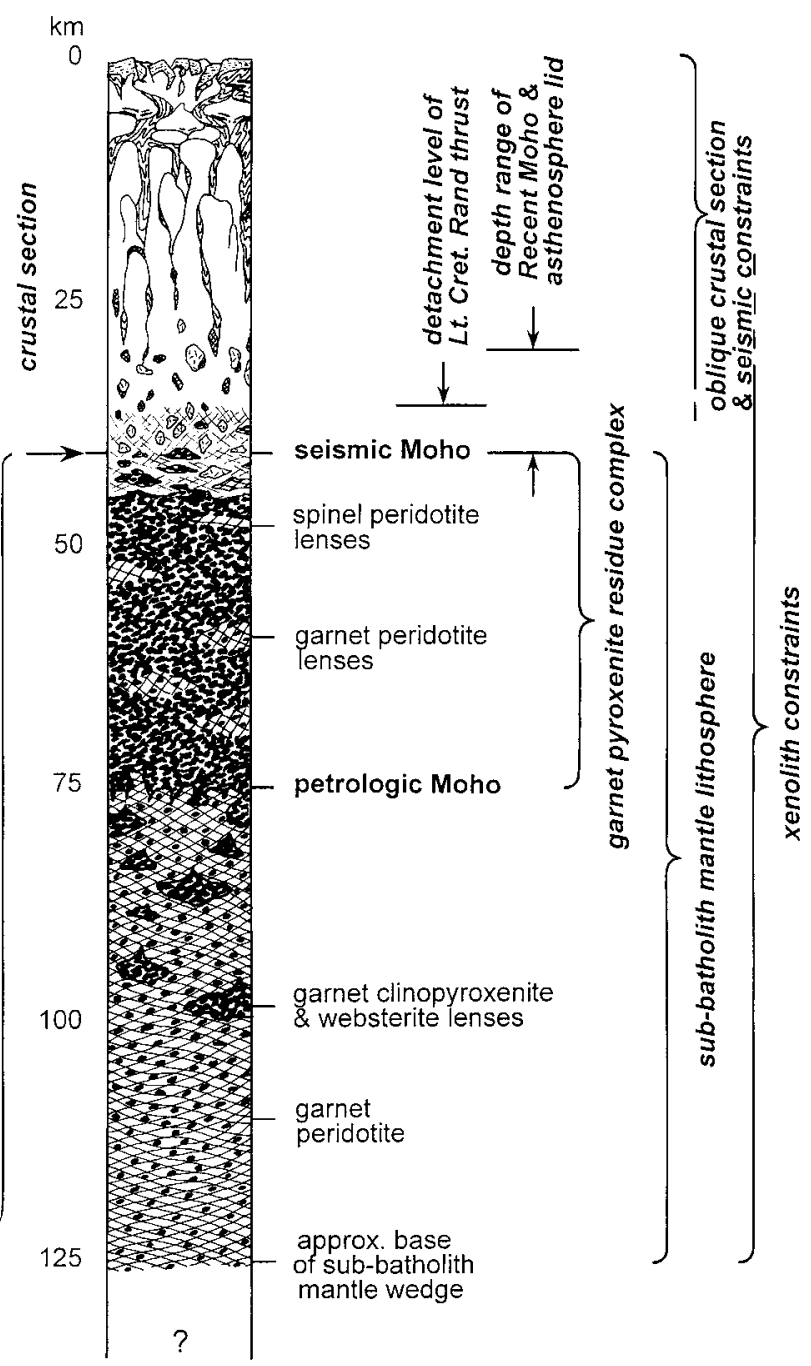

Figure 4. Reconstructed primary lithospheric column for axial and eastern domains of the Cretaceous Sierra Nevada batholith based on P-T relations (Figure 2a) and relative abundances of lower crust-upper mantle rock types comprising the mid-Miocene xenolith suite [Ducea and Saleeby, 1998a], map relations of the oblique crustal section through the southern Sierra Nevada batholith [Saleeby, 1990], and regional seismic data [Jones and Phinney, 1998; Ruppert et al., 1998; Fliedner et al., 2000].

struction is based on are in agreement with deep seismic data across the shallow-level exposures of the batholith to the north of the oblique crustal section [Jones and Phinney, 1998; Ruppert et al., 1998; Fliedner et al., 2000]. Fliedner et al. [2000] also note that the seismic velocities measured for the deep felsic batholith are slightly low for typical batholithic crust, which can be reconciled by a strong regionally consistent anisotropy along the trend of the batholith. Regional field relations show such a pervasive anisotropy along the trend of the batholith, expressed most strongly at $\sim 0.3 \mathrm{GPa}$ and greater depths [Saleeby, 1990]. This consists of the NW trending and steeply dipping tabular shapes of plutons and their internal contacts, solidus to hot subsolidus flow fabrics, and the pervasive structure of high-grade metamorphic pendants. The steep regional primary fabric of the batholith continues downward to between 0.8 and $1 \mathrm{GPa}$ levels. It is clear from the oblique crustal section that the crust has been completely reconstituted by batholith production.

[22] The felsic batholith grades into a mafic granulite layer at $\sim 1 \mathrm{GPa}$ conditions. Within the transition zone there are gabbronorite and pyroxene quartz gabbrodiorite intrusions which resemble granulites, but are mantlederived magmatic rocks that had variably fractionated as they entered the lower crust. Layers and small irregular shaped intrusions of mantle-derived hydrous (hornblende rich) mafic and ultramafic cumulates are also common at this structural level. On the basis of direct observations of 


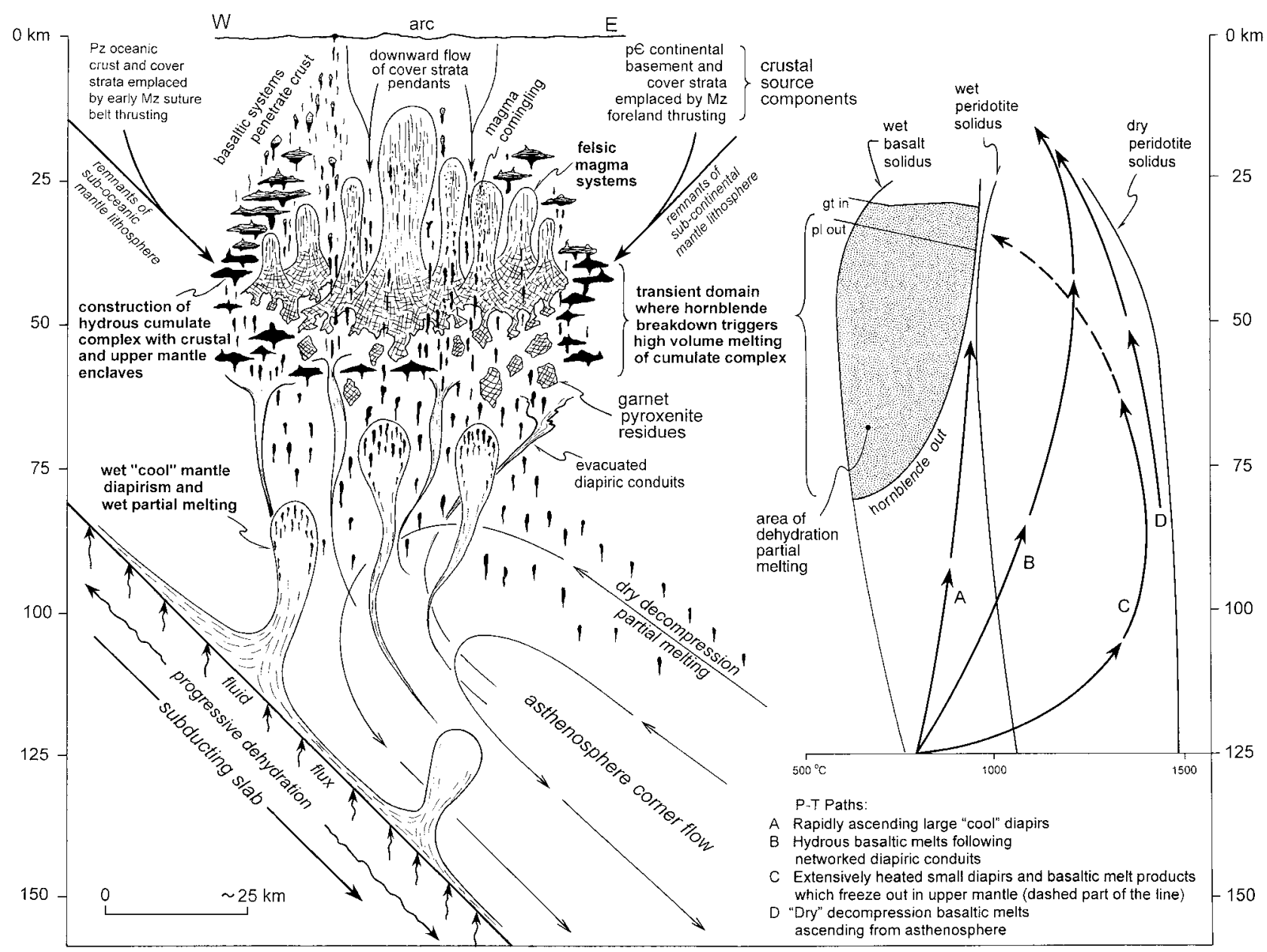

Figure 5. Model for the evolution of the lower crust and mantle wedge that developed in conjunction with the formation of the Sierra Nevada batholith based on petrogenetic data from the mid-Miocene xenolith suite, observations at the lower levels of the oblique crustal section of the Sierra Nevada batholith, and models of fluid transfer, corner flow circulation and diapirism that are discussed in the text. The P-T plot registered to depth axis shows critical phase boundaries and solidi from Figure 2a and P-T paths for several different dynamic systems that are thought to populate active mantle wedge environments [after Hall and Kincaid, 2001; Asimow, 2002]. The model, in essence, shows the two-stage development of the felsic Sierra Nevada batholith entailing the production of a lower crust-uppermost mantle hydrous cumulate complex derived from wet wedge-derived basaltic magmas and then the dehydration remelting of the complex and its host framework to render large volume felsic magmas and garnet pyroxenite residues. gt, garnet; pl, plagioclase.

the deep-level rocks and the phase relations summarized in Figure 2a, the garnet granulites are interpreted for the most part as residues left from the partial melting of hydrous mafic to intermediate composition rocks at $\sim 1 \mathrm{GPa}$ conditions. The granulite layer is relatively thin $(\sim 5 \mathrm{~km})$ and grades downward into feldspar-free residues of the garnet pyroxenite complex, which is $\sim 35 \mathrm{~km}$ thick. The transition from feldspathic to feldspar free residues/cumulates corresponds to the seismic Moho. Petrogenetically the garnet pyroxenites are crustal rocks, having evolved in the deep crustal magma genesis domain and having the isotopic fingerprints of crustal rocks. Accordingly, the base of the garnet pyroxenite complex corresponds to the petrologic Moho. We adhere to a seismic velocity definition for the Moho thereby placing most of the garnet pyroxenite complex within the subbatholith mantle lithosphere.

\section{Production of the Subbatholith High-Density Root}

[23] The production of the high-density root for the Sierra Nevada batholith entailed processes that operated over the entire mantle wedge above the Cretaceous subducting slab. Figure 5 presents a model for the evolution of the lower 
crust and mantle wedge beneath the batholith, and its relationship to batholith genesis. The tectonic section along the left side of the diagram depicts the formation of the batholith by a two-stage process which starts with hydrous basalt magma generation in the mantle wedge. These magmas are shown diagrammatically to form a hydrous mafic cumulate complex at and below the base of the crust. Much of this complex is depicted to then undergo dehydration partial melting to form felsic magmas and garnet clinopyroxenite residues. The tectonic section also depicts the two distinct crustal reservoirs that were tectonically constructed as the host framework into which the deeplevel cumulate complex was emplaced. Remelting of the cumulate complex also entailed the melting and incorporation of these crustal reservoirs. The P-T plot along the right side of the diagram is explained below.

[24] The peridotite xenoliths of the mid-Miocene suite are interpreted as vestiges of the mantle wedge. On the basis of Os isotopic data, Lee et al. [2000, 2001] interpret a subset of these xenoliths to be asthenosphere affinity mantle that replaced mantle lithosphere during a Cretaceous to early Cenozoic delamination event. These workers did not consider the garnet pyroxenite complex in their analysis, having lumped such rocks into the overlying crust. However, there are significantly more such pyroxenite xenoliths than peridotites in the suite, and those studied in detail show substantial overlap in pressures (depths) with the peridotites (Figure 2a). We offer an alternative interpretation that considers the petrogenesis of the entire suite. Geodynamic studies of mantle wedges [Billen and Gurnis, 2001; Hall and Kincaid, 2001; Jull and Kelemen, 2001; Zhao, 2001] suggest weak low-viscosity conditions as well as high "Moho" temperatures ( 800 to $900^{\circ} \mathrm{C}$ at $\left.\sim 1.2 \mathrm{GPa}\right)$. An important result of a weak low-viscosity wedge is a vigorous subduction-driven corner flow pattern which taps asthenospheric reservoirs and pulls such materials up into the wedge environment. Such an influx of nondepleted asthenospheric mantle is required in order to sustain magmatism for 10's of m.y. without exhausting the source regime, a condition required for the Cretaceous Sierra Nevada batholith. Furthermore, the flux of fluids into the wedge via dehydration reactions in the subducting slab is suggested to induce a second-order dynamic system that is superposed over the counter flow pattern, as well as drive wet partial melting [Elliott et al., 1997; Schmidt and Poli, 1998; Hall and Kincaid, 2001; Ulmer, 2001; Zhao, 2001]. These and other supporting studies predict a significant drop in both fertile peridotite solidus temperatures and viscosity, and high water contents in the derivative basaltic melts with a corresponding increase in melt buoyancy. A profound prediction is the generation of relatively "cool" peridotite diapirs along the base of the water saturated wedge, and rapid ascent of such diapirs through the asthenosphere counter flow pattern. Depending on ascent rate such compositionally controlled diapirs are variably heated in the hot domains of the counter flow pattern as well as comingle with the attendant decompression partial melts. Depending on the extent of heat exchange the diapirs can also undergo substantial wet partial melting.
[25] The right margin of Figure 5 shows a P-T plot that is registered to the depth axis of the tectonic section. The wet and dry peridotite solidi, the wet basalt solidus and some of its critical mineral reaction boundaries are plotted (after Figure $2 \mathrm{a}$ and references therein). Four theoretical P-T paths are shown on the plot for different dynamic systems that are thought to populate the wedge environment. Paths A through $\mathrm{C}$ originate at the wedge-slab interface [after Hall and Kincaid, 2001]. A is the path of a rapidly ascending "cool" diapir that penetrates the corner flow pattern without substantial heating. B is the path of hydrous basaltic melts that form along the margins of slower-moving diapirs as well as in networked systems of diapiric conduits. $\mathrm{C}$ is the path of small diapirs and their hydrous basaltic melt products that are extensively heated as they move through the corner flow pattern. The relationship between heat exchange and ascent rate not only promotes substantial partial melting along path $\mathrm{C}$, but also cooling in the upper wedge which results in the freezing out of the basaltic melts. Path D is synthesized from Asimow [2002], and approximates the path of a basaltic melt that forms by decompression partial melting within the upper levels of the asthenosphere corner flow pattern with little or no heat exchange during melt segregation and ascent. These theoretical P-T paths are used below in the development of a model for the construction of the subbatholith wedge peridotite and batholith residue sequence represented by the mid-Miocene xenolith suite.

[26] The high-T peridotite array (Figure 2a) lies roughly along the wet peridotite solidus. We interpret these xenoliths to represent vestiges of the last asthenosphere affinity mantle to circulate into the wedge by a combination of corner flow and superimposed "cool" diapirism, and to undergo variable amounts of mainly wet partial melting. In addition to the P-T trajectory of the high-T array shown on Figure $2 \mathrm{a}$, some of the key features of these peridotites are their variably depleted states, isotopic heterogeneity with a well-represented asthenosphere endmember, and evidence for decompression. Additionally, some minor phases in the peridotites show evidence for fluid influx carrying $\mathrm{Ba}, \mathrm{K}, \mathrm{Rb}, \mathrm{U}, \mathrm{Th}$, halogens and radiogenic $\mathrm{Pb}$, and some show the effects of pervassive metasomatic alteration [Mukhopadhyay and Manton, 1994]. In aggregate these features suggest alteration by slab-derived fluids and wet partial melting during ascent and decompression. A combination of peridotite diapirs stalling out along path $\mathrm{A}$ with peridotite residues left in evacuated conduits along path $B$ could generate the high- $T$ array of the peridotite data. The critical question is what would promote such stalling of the mantle wedge dynamic system? This question is part of a larger question that concerns the survival of the mantle wedge complex for $\sim 70$ m.y. following the cessation of Sierran arc magmatism, until the time of xenolith entrainment. We will return to these questions as well as the cooling history of the mantle wedge in the next section.

[27] The principal driving process depicted in Figure 5 for the ultimate production of the felsic batholith is basalt magma genesis in the lower to medial levels of the wedge. In particular the construction of a thick complex of hydrous 
cumulates is envisaged at and below the base of the crust. Hydrous basaltic magmas ascending along path $\mathrm{C}$ are the likely major contributors in the construction of such a deeplevel cumulate complex. The wet basaltic systems that are seen to penetrate the crust and fractionate at shallow levels are considered to have followed a path more like B. There is probably a continuum between these two paths, as there probably is between paths A and B. There is some evidence to suggest that drier basaltic systems which also penetrate the crust, and conceivably represent path D systems, use the same conduits as the wet systems of path B. This is expressed along the western domain of the batholith in numerous areas where masses of hornblende-rich cumulates are cut by virtually coeval drier gabbronorite to pyroxene quartz gabbrodiorite intrusive sequences [Mack et al., 1979; Saleeby and Sharp, 1980; Clemens-Knott and Saleeby, 1999]. Thus a continuum of wet to relatively dry, and hot to relatively cool basaltic magma systems is envisaged to flux out of the lower to medial levels of the mantle wedge and to fractionate over a tremendous depth interval to form a lower crust-uppermost mantle cumulate complex as well as higher-level crustal intrusive sequences, and at the surface basalt-andesite volcanic centers. It is the construction of a thick basal hydrous cumulate complex which is considered the essential element in the ultimate production of the large volume felsic batholith. The existence of the deep-level cumulate complex, as such, is depicted on Figure 5 as a transient phenomena.

[28] The P-T plot on Figure 5 shows the wet basalt solidus and the related hornblende out boundary (after Figure $2 \mathrm{a}$ and references therein). Hornblende is one of the principal phases in the cumulates occurring as both a cumulate and intercumulate phase in gabbros, melagabbros and pyroxenites. Such early liquidus behavior of hornblende in wet basaltic systems is constrained by experimental and theoretical data to occur at roughly $1000^{\circ} \mathrm{C}$ over the 1-2 GPa pressure range [Wyllie, 1971, p. 202]. Thus at the 1-2 GPa levels the temperature of a given cumulate mass is initially very close to the hornblende out boundary as determined by dehydration melting experiments. Presumably some cooling of the cumulates occurs as heat is transferred into the host framework rocks. However, ambient temperatures are high $\left(800^{\circ}-950^{\circ} \mathrm{C}\right)$ as suggested by the dynamic models referenced above, and as recorded in the thermobarometric data for the base of the oblique crustal section as well as the granulite, lowest-P garnet pyroxenite and shallow-level heated peridotite xenoliths (Figure 2a). These relations suggest that conditions in the uppermost mantle and lowermost crust remained very close to the hornblende out boundary during growth of the cumulate complex as well as during felsic magma genesis.

[29] Experimental studies on the melting properties of hydrous mafic systems indicate that small degrees of partial melt of felsic composition are present in the P-T field between the wet basalt solidus and the hornblende out boundary [Wolf and Wyllie, 1993, 1994; Rapp and Watson, 1995; Vielzeuf and Schmidt, 2001]. This corresponds to the shaded area of the Figure 5 P-T plot. It is the accelerated breakdown of hornblende near and across its "out" bound- ary that triggers higher volume melting, and when felsic melt fractions reach 5-10 volume \% melt segregation and migration are instigated [Wolf and Wyllie, 1995]. The relative proportions of felsic batholith and garnet pyroxenite residues shown in Figure 4 suggests that partial melting possibly reached $\sim 50 \%$. In the Figure 3 plots of residual phase modes based on thermodynamic modeling of the dehydration partial melting of a pertinent basalt, felsic melt compositions suitable for the Sierra Nevada batholith are produced at melt fractions of between 10 and 55 percent. Since most of the garnet pyroxenite xenoliths lack hornblende, we are led to conclude that such partial melting occurred at or even above the hornblende out boundary. These are the conditions that would be most conducive for high-volume felsic melt production, segregation and migration.

[30] We suggest that the deep-level cumulate complex and much of its host framework were pervaded with small amounts of interstitial felsic melt, perhaps for extended periods of time. As intensified fronts of accelerated and/or complete hornblende breakdown and water liberation were superposed over these ambient conditions high-volume felsic magma production ensued. As felsic melt fractions exceeded $10 \%$ segregation and ascent of felsic batholithic magmas commenced. Higher melt fractions presumably reflect accelerated hornblende breakdown episodes. A number of processes can result in such accelerated partial melting episodes. Rapid fluxes of wedge derived magmas can periodically depress the base of the complex by the addition of cumulates and by higher-level crustal construction. Such "crustal" thickening can push the lower levels of the complex toward and across the hornblende out line. High fluxes of magma into and through the complex can also advect heat and fluids into the complex. Episodes of intense heating may also occur by the emplacement of peridotite diapirs. Additionally, crustal thickening by backarc thrusting can also depress the base of the complex across the hornblende breakdown boundary. As discussed above, the ambient temperatures are probably high enough in the upper wedge environment that any one or combination of these mechanisms could potentially drive episodes of rapid high-volume felsic melt production.

[31] The garnet pyroxenite complex is envisaged to have developed sequentially in large batches as volumetrically comparable batches of felsic melt formed, gathered and ascended. Throughout this partial melting and melt extraction process variably fractionated wedge-derived mafic magmas continued to invade the felsic magma source regime thereby supplying additional heat, fluids and if fractionated labile components. Those invading magmas that penetrated high enough into and through the source regime were entrained in, and commingled with the respective felsic magmas, a common mesoscopic feature observed in the batholith. Large batches of garnet pyroxenite residues are also suggested to have foundered gravitationally into the wedge peridotites, below the level of felsic magma production. Some may have settled through the wedge to join the descent of the subducting slab. The felsic magma source regime is thus considered a complex zone that was both 
built and penetrated by ascending hydrous basaltic magmas, evacuated by felsic magmas, and occupied by increasing proportions of garnet pyroxenite residues. As such a dynamic structure evolves it would yield a broad transition zone between mantle and crustal seismic velocities like that imaged beneath the active Andean arc [Graeber and Asch, 1999].

[32] Extensive partial melting of the deep level cumulate complex also involved the partial melting of its host framework. As shown diagrammatically on Figure 5, potentially important regionally extensive framework rocks include: (1) Paleozoic ophiolitic mafic crust and overlying Mesozoic volcanic-sedimentary sequences of the western metamorphic belt that may have been thrust eastward into the prebatholithic framework in early Mesozoic time [Saleeby, 1981]; and (2) Proterozoic deep continental crust and its cover strata that may have been emplaced westward into the source regime prior to and/or during batholith generation in the root zone of the Cordilleran foreland thrust system [Saleeby, 1981, 1999; Ducea, 2001]. The westernmost (backarc) branch of this regional thrust system is shown on Figure 1. The extent to which the western oceanic crustal framework rocks were contributed to the source regime is difficult to assess because the resulting geochemical signals would resemble those of the asthenospheric + slab fluid component. A Proterozoic lower continental crustal component is recorded in the eastern domain of the batholith as well as some garnet pyroxenite xenoliths by $\mathrm{Sr}$, $\mathrm{Nd}$ and $\mathrm{Pb}$ isotopic variation patterns [Chen and Tilton, 1991; Ducea and Saleeby, 1998a; Zeng et al., 2001b]. Both the western oceanic and eastern continental basement complexes possessed sedimentary cover strata that are shown to be a moderate to subordinate source component by both batholith and xenolith isotopic data [Saleeby et al., 1987; Kistler, 1990; Clemens-Knott, 1996; Ducea and Saleeby, 1998a; Lackey et al., 2002], as well as direct observations of pendant and hosting batholithic rocks at $\sim 0.5 \mathrm{GPa}$ levels and deeper. Nowhere in the exposed deep-level metamorphic pendants are there direct remnants of melted oceanic mafic basement nor Proterozoic continental basement. High-grade pendant rocks consist totally of supercrustal protoliths and the melting of their labile components is shown to only locally affect the composition of the batholith [Clemens-Knott et al., 1991; Pickett and Saleeby, 1994; Zeng et al., 2001b]. Thus the principal contributions of the framework basement components and their cover strata to the batholith source regime occurred at structural levels beneath that represented by the metamorphic pendants, even at the deepest exposed levels of the batholith. This structural level is depicted on Figure 5 to have been at the depth where they formed the host framework for the deep-level cumulate complex. In this setting such crustal rocks constituted highly labile components vulnerable to wet partial melting and mixing into the felsic magma systems.

\section{Loss of the Subbatholith High-Density Root}

[33] In a recent review of continental lithospheric structure and composition O'Reilly et al. [2001] assert that relative to Archean and Proterozoic lithospheric domains Phanerozoic subcontinental mantle lithosphere is more prone to delaminate and sink through the asthenosphere. The primary driving force invoked is the negative buoyancy of Phanerozoic mantle lithosphere, due to its relatively nondepleted state which to a first order translates to higher $\mathrm{Fe} / \mathrm{Mg}$ ratios in olivine and pyroxenes and higher $\mathrm{Al}$ contents which stabilizes garnet. Various workers have suggested mantle lithosphere delamination events for a variety of times and tectonic settings in the southwest U.S. [Bird, 1979, 1988; Ducea and Saleeby, 1998b; Lee et al., 2000, 2001]. The supporting evidence as well as the tectonic settings of these presumed delamination events vary greatly. The dynamic processes that potentially govern such delamination events are varied as well. For example, Bird [1979, 1988] discusses mechanical delamination in which high-density mantle lithosphere is peeled away along a surface of relative weakness, such as the Moho, or is sheared away by flat-slab subduction. In contrast, convective instabilities have been invoked as a mechanism to remove lithosphere and lower crust [Conrad and Molnar, 1997; Houseman and Molnar, 1997b; Houseman et al., 2000; Jull and Kelemen, 2001]. Key to this analysis are density perturbations resulting from temperature contrasts that are convectively removed. Jull and Kelemen [2001] have added to this analysis upper lithosphere density contrasts introduced by the growth of mafic-ultramafic cumulate sequences in the roots of magmatic arcs. In their analysis they point out the compounding effect of high temperature and high initiating regional strain rates in instigating the convective instability. In the discussion below we rely on elements of all these mantle lithosphere removal mechanisms to explain geological and geophysical relations which suggest that at least two distinctly different mantle lithosphere removal events affected the southern Sierra Nevada region. We distinguish between mechanical delamination and convective removal, but assert that the regionally planar contact zone between the felsic batholith and its underlying garnet pyroxenite residue complex was the preferred locus of separation for both mechanisms. It may also be argued that the reconstitution of the sub-Sierran lithosphere that is envisaged to have accompanied batholith production (Figure 5) also entailed the removal of the preexisting subcontinental mantle lithosphere [cf. Lee et al., 2000, 2001]. We suggest that the concept of mantle lithosphere delamination is not applicable in this case. In contrast piecemeal replacement of tectonically sutured oceanic and continental mantle lithosphere remnants by asthenosphere counter flow, mantle diapirism and the ascent of voluminous wedge-derived basaltic magmas seems conceptually more applicable. Regardless, our focus below is on the removal of the subbatholith mantle lithosphere as its structure is depicted in Figure 4.

[34] The mantle lithosphere section depicted in Figure 4 sat beneath the Sierra Nevada batholith at the time of its $\sim 80$ Ma termination of magma genesis. Integration of field data, Pliocene-Quaternary volcanic-hosted xenolith studies, and geophysical data for the southern Sierra region reveals that much of the subbatholith mantle lithosphere was 


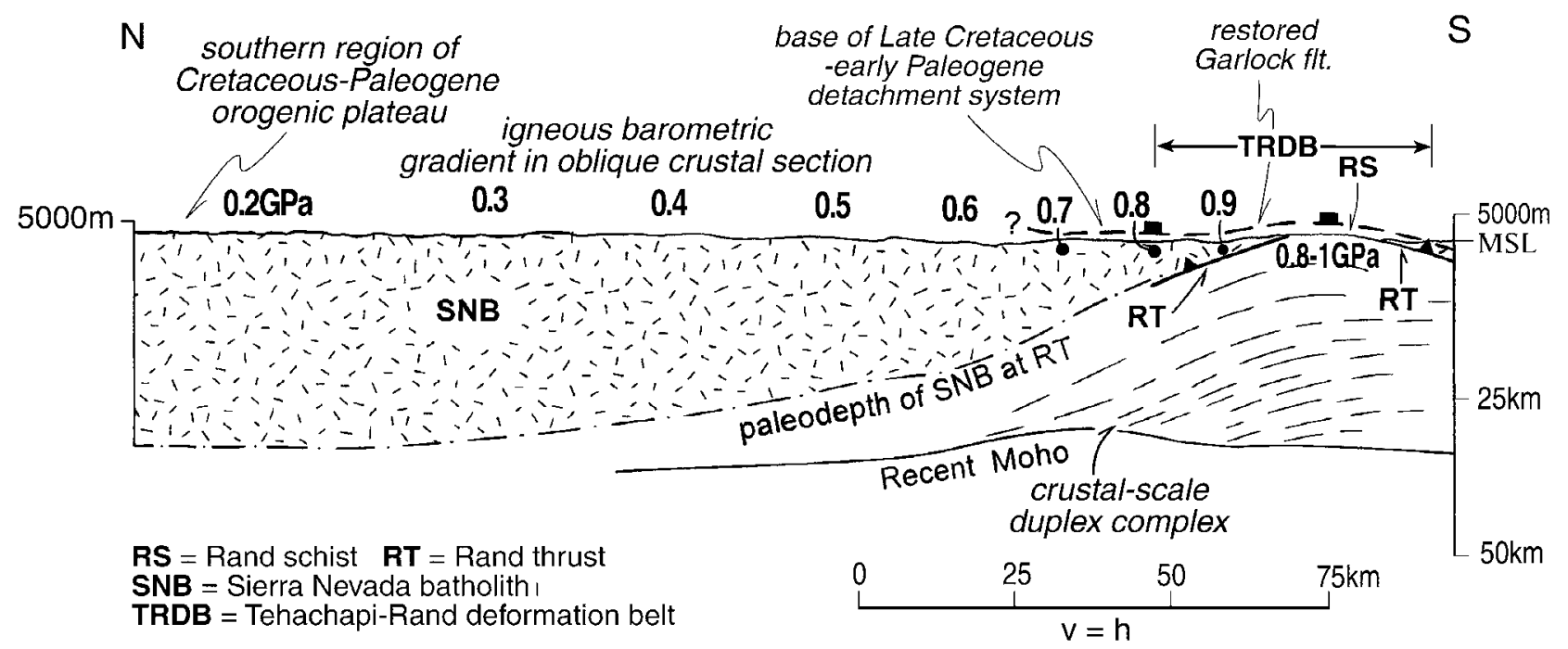

Figure 6. Generalized longitudinal cross section along the southernmost Sierra Nevada batholith and across the Tehachapi-Rand deformation belt. The location of the section line is on Figure 1 (note restoration of Garlock fault). The structure of Rand thrust, restorations of high-angle faults, and correlations of western Tehachapi Range with Rand Mountains are after Cheadle et al. [1986] and Malin et al. [1995]. The geobarometry of the Rand schist is after Sharry [1981] and Jacobson [1995] and of the batholith after Ague and Brimhall [1988], Pickett and Saleeby [1993], and Ague [1997]. The base of the Late Cretaceous-early Paleogene detachment system is after Wood and Saleeby [1998] and Saleeby [2003]. The southern region of the Late Cretaceous-early Paleogene orogenic plateau is after House et al. [1997a, 2001]. The level of lower crust detachment observed along the Rand thrust is projected northward along the section line and is observed to coincide with the regional dip of the oblique crustal section as defined by the batholith geobarometric gradient.

removed during two distinct events that occurred in contrasting tectonic settings: (1) latest Cretaceous-Paleocene (Laramide) subduction tectonics for the southernmost Sierra region; and (2) late Neogene high magnitude (Basin and Range) extensional tectonics for the greater Sierra Nevada batholith to the north.

\subsection{Laramide Delamination in the Southernmost Sierra Nevada Region}

[35] The Laramide orogeny is recognized as a regional compressional event that deformed the southwest North American craton in latest Cretaceous-early Paleogene time [Miller et al., 1992]. A widely accepted plate tectonic mechanism for the Laramide orogeny is the intensified traction and tectonic erosion along the base of the continental lithosphere resulting from the flattening of the subduction trajectory of the Farallon plate [Coney and Reynolds, 1977; Dickinson and Snyder, 1978; Bird, 1988]. Geologic events along the southwest North American plate edge that have been attributed to Laramide flat slab subduction include the end of magmatism in the Sierra Nevada batholith and associated modification of the subbatholithic geotherm, and the deep crustal emplacement of subduction accretion assemblage (Rand and related schists) beneath the axial regions of the batholith in the southernmost Sierra and adjacent Mojave Desert [Dumitru et al., 1991; Malin et al., 1995; Jacobson et al., 1996; Jacobson, 2000; Saleeby,
2003]. Constraints on the lower crust upper mantle structure posed by the oblique crustal section of the southern Sierra, along with seismic data and constraints posed by the midMiocene xenolith suite carry important implications on the topology of the Laramide "flat" slab.

[36] The subbatholith mantle lithosphere survived in the central Sierra Nevada region at least until mid-Miocene time, when it was sampled as xenoliths by deep-seated volcanism. We do not consider accidental sampling of a tectonically telescoped section as a viable alternative to the sampling of an intact section. Cumulate and/or annealed textures of high-grade mineral assemblages greatly predominate over retrograde tectonic fabrics in the deep-level xenolith suites. Furthermore, the mid-Miocene xenolith suite lacks high $\mathrm{P} / \mathrm{T}$ metamorphic assemblages and subduction rock assemblages, whose tectonic underplating should have accompanied such telescoping. Our conclusion for these observations is that flat slab subduction did not disrupt the subbatholith mantle lithosphere of the central Sierra Nevada region.

[37] The intact lithospheric structure exhibited for the central Sierra Nevada batholith contrasts sharply from that observed along the Tehachapi-Rand deformation belt. This is readily visualized by inspection of the longitudinal cross section of Figure 6 . Here we have palinspastically restored offset on late Neogene high-angle faults in order to elucidate the first-order structural relations of the deformation belt [Malin et al., 1995; Saleeby, 2003]. The southernmost 
Sierra (Tehachapi) seismic reflection structure correlates with the northern Mojave seismic reflection structure adjacent to the Rand Mountains [Cheadle et al., 1986]. In both areas field observations and seismic data indicate that the base of the batholithic crust and its underlying mantle lithosphere have been tectonically removed in conjunction with the emplacement of the Rand schist beneath the Rand thrust [Cheadle et al., 1986; Silver and Nourse, 1986; Malin et al., 1995; Wood and Saleeby, 1998; Miller et al., 2000; Saleeby, 2003]. The Rand thrust is exposed in the core of an antiformal window in the Rand Mountains, and to the north in the southernmost Sierra as small half windows and larger fault-bounded slices along the Garlock fault (Figure 1). Seismic reflection and refraction data for the western Mojave Desert region to the south indicate that the Rand schist (and thrust) underlies much or all of the region, and that the residual upper plate batholithic crust forms a relatively thin upper crustal layer [Li et al., 1992; Z. Yan et al., Seismic evidence for steep faults cutting highly attenuated continental basement in the central Transverse Ranges, California, submitted to Journal of Geophysical Research, 2003]. Thermobarometric constraints along the Tehachapi-Rand belt indicate that the level of such mechanical delamination of the lower crust along the Rand thrust was between 0.8 and $1 \mathrm{GPa}$ [Sharry, 1981; Pickett and Saleeby, 1993; Jacobson, 1995]. Geochronologic data indicate that this occurred between 80 and $85 \mathrm{Ma}$ [Silver and Nourse, 1986; R. W. Kistler, written communication, 1997].

[38] The seismic reflection structure beneath the Rand thrust along the Tehachapi-Rand belt [Cheadle et al., 1986; Malin et al., 1995] suggests that the schist forms a near crustal-scale duplex complex (Figure 6). The seismic reflection data also show the Rand thrust dipping $\sim 20^{\circ}$ north beneath the southernmost Sierra Nevada batholith as it extends northward from its surface exposure along the deformation belt. The paleodepth gradient (pressure gradient, Figure 6) within the upper plate batholith is compatible with the tilt of the crustal section based on the dip of the seismic reflection structure. The implication is that the level of mechanical delamination of the lower batholithic crust by the Rand thrust approximated the base of the felsic batholith over a wide region. We suggest that this regional delamination horizon resulted from the preferential removal of the garnet pyroxenite complex which was the southward continuation of that which remained intact beneath the greater Sierra Nevada batholith to the north. In addition to structural continuity along the oblique crustal section, the overall petrologic and isotopic character of the batholith is continuous, and REE data for the deep felsic batholithic rocks in the south, as to the north, are consistent with a garnet-rich residue in their source [Ross, 1989].

[39] The termination of arc magmatism for the greater Sierra Nevada batholith to the north of the Tehachapi-Rand deformation belt occurred in the same 80 to $85 \mathrm{Ma}$ time interval as Rand thrust emplacement [Evernden and Kistler, 1970; Stern et al., 1981; Chen and Moore, 1982; Saleeby et al., 1987]. This must be considered an early Laramide event as well. It has been suggested from the modeling of fission track data that the base of the central Sierra Nevada batholith was removed by Laramide flat slab subduction at a depth of between 35 and $50 \mathrm{~km}$ [Dumitru, 1990; Dumitru et al., 1991]. This assertion is at odds with the xenolith data (Figures 2 and 4). Furthermore, the fission track data basis for the model needs reevaluation in the light of more recent $\mathrm{He}$ dating performed in the same region [House et al., 1997a, 2001]. Most notable are the effects of cooling by early unroofing, and the development of high topographic relief as shown by the He data. The key element in Dumitru's [1990] model is conductive cooling of the Sierran lithosphere, or residual crust, from beneath by the Laramide slab. In spite of our rejection of Dumitru's [1990] conclusion that the Laramide slab removed the mantle lithosphere from beneath the greater Sierra Nevada batholith, the xenolith data records a mantle lithosphere-scale conductive cooling regime. As discussed above this is recorded in the orthopyroxene zonation cooling histories in a number of the deep and medial level peridotite xenoliths, and by the phase relations in the deep to medial level garnet pyroxenite xenoliths. Such cooling does not appear to be recorded in the uppermost mantle-lowermost crustal xenoliths (Figure 2a). Thermal modeling of the peridotite orthopyroxene cooling histories is consistent with a conductive cooling regime established at the onset of the Laramide orogeny [Lee et al., 2000, 2001]. The evolution of the mantle wedge and batholith source regime discussed above envisages a highly dynamic environment of subduction driven wedge corner flow, superimposed diapirism and the resulting copious production of hydrous basaltic magma. This dynamic system was in a sense "quenched" at the onset of the Laramide orogeny, and then conductively cooled over an extended period of time. Such conductive cooling of an $\sim 125 \mathrm{~km}$ thick lithospheric section will penetrate to crustal and surficial levels at a 100 m.y. timescale. This is reflected today by low surface heat flow in the Sierra Nevada region [Saltus and Lachenbruch, 1991].

[40] The Laramide age termination of arc magmatism throughout the greater Sierra Nevada batholith, with the preservation of its underlying mantle lithosphere, is attributed to the disruption of the mantle wedge corner flow pattern which drove arc magmatism. There are a couple of different factors in Laramide subducting slab topology and kinematics that could have resulted in this event. The modern Andean subduction arc system is commonly cited as an actualistic model for the Laramide tectonics of SW North America. A critical feature of the Andean system is the segmentation of the down-going slab into normal, intermediate and shallow domains with variable dips [Barazangi and Isacks, 1976; Jordan et al., 1983; Gutscher et al., 2000]. As suggested by Malin et al. [1995] and Saleeby [2003] we assert that the contrast in the deep crust and upper mantle structure between the greater Sierra Nevada batholith and the southernmost Sierra and adjacent Mojave Desert batholith resulted from a segmentation in the Laramide slab. Imaging of sub-Andean slab morphology by Gutscher et al. [2000] shows flat segments as shallow as $\sim 50 \mathrm{~km}$ and as deep as $\sim 120 \mathrm{~km}$, in addition to steeply dipping segments which typically underlie areas of active arc magmatism. Such segmentation of the Laramide slab under the southern 
Sierra into two such flat domains could render the along strike variations in deep crust-upper mantle structure observed between the greater Sierra Nevada and the southerntmost Sierra-Mojave region. In the south a shallow flat segment mechanically delaminated the subbatholithic mantle lithosphere and in its place accreted subduction assemblages that were displaced downdip into the shallow subduction zone. To the north the deeper flat slab segment left the lithosphere intact, but disrupted the mantle wedge corner flow pattern which resulted in the "quenching" of the mantle wedge, and its ensuing conductive cooling. Billen and Gurnis [2001] offer a dynamic analysis of the termination of mantle wedge corner flow by slab flattening. Another possible contributing factor [Saleeby, 2003] is that by viewing the slab segmentation deformation regime on a pre-Neogene palinspastic base, in conjunction with Farallon-North American relative plate motions, it appears that the shallow slab segment followed a trajectory beneath SW North America that was highly oblique in a dextral sense. This trajectory thus impinged sharply into the proximal backarc region of the greater Sierra Nevada batholith which conceivably led to further interference with the wedge corner flow pattern.

\subsection{Late Neogene Convective Removal in the Greater Sierra Nevada Batholith Region}

[41] The mid-Miocene and Pliocene-Quaternary xenolith suites contrast profoundly in composition, petrogenesis and physical conditions of equilibration (Figure 2b). Most notable is the lack of garnet pyroxenite and garnet peridotite samples in the Pliocene-Quaternary suite. The contrasts between the two xenolith suites are too extreme and consistent to be attributed to accidental sampling bias. Another contrast between the two suites is the presence of common glass inclusions in the Pliocene-Quaternary suite, which are lacking in the mid-Miocene suite with one important exception that is discussed below. Furthermore, all attempts to date the younger suite yield Recent ages [Ducea, 1998]. These findings further support the modern asthenospheric origin for the younger peridotites as suggested by their P-T field shown on Figure 2b. The two xenolith suites thus appear to record the evolution of the composition and physical state of the sub-Sierran upper mantle through Cenozoic time.

[42] Figure 7 synthesizes the results of recent geophysical studies in the southern Sierra Nevada region, and presents a geological interpretation of these results based on the xenolith studies. Regional seismic refraction studies show a crustal thickness of 30 to $35 \mathrm{~km}$ across the main part of the batholith, as exposed at 0.1 to $0.3 \mathrm{GPa}$ levels, and westward thickening to an $\sim 40 \mathrm{~km}$ deep depression beneath the western domain of the batholith [Ruppert et al., 1998; Fliedner et al., 2000]. The refraction studies also show Vp of $\sim 6.0 \mathrm{~km} / \mathrm{sec}$ extending down to the Moho under the main part of the batholith, which is consistent with the oblique section exposures to the south indicating the predominance of felsic batholithic rocks to $\sim 35 \mathrm{~km}$ depths. Velocities as high as $6.4 \mathrm{~km} / \mathrm{sec}$ are resolved within the crust beneath the western mafic domain. The refraction data also reveal low Pn velocities and along with regional passive experiments indicate a lack of a mantle lithosphere lid along the eastern Sierra-Owens Valley region [Jones and Phinney, 1998; $J i$ and Helmberger, 1999; Melbourne and Helmberger, 2001]. Geophysical data as well as observations of glass inclusions in Pliocene-Quaternary xenoliths reveal the presence of partial melt in the shallow upper mantle of the region [Ducea and Saleeby, 1998c; Park et al., 1996; Jones and Phinney, 1998]. The modern lithosphere-asthenosphere boundary virtually corresponds to the Moho beneath much of the southern and in particular eastern Sierra Nevada region. Jones and Phinney [1998] further discuss evidence for a tectonized and lithologically interlayered Moho in this region which is consistent with the occurrence of highly tectonized felsic batholithic rocks in the PlioceneQuaternary xenolith suite [Ducea and Saleeby, 1996].

[43] Teleseismic data further reveal a high-velocity mass within the upper mantle beneath the western Sierra and adjacent southeastern Great Valley [Zandt and Carrigan, 1993; Jones et al., 1994; Ruppert et al., 1998]. Jones et al. [1994] refer to this mass as a mantle "drip", a term that we adopt and which implies its formation by convective processes. According to the tomogram published in Ruppert et al. [1998], the drip extends downward from near Moho depths and attains its strongest definition between 100 and $225 \mathrm{~km}$ depths. The velocity contrast between much of the drip and the adjacent mantle is sufficiently high to warrant its interpretation as "eclogitic". The drip is bounded to the east by a domain of low-velocity mantle which merges with the low Pn mantle rocks beneath the Sierran Moho. In the analysis that follows we consider the mantle drip to be the remnants of the convectively removed subbatholith mantle lithosphere. The "eclogitic" composition interpreted for the drip is consistent with much of it having been derived from the garnet pyroxenite residue complex.

[44] Calculated densities of Sierran garnet pyroxenite xenoliths are on average $0.2 \mathrm{~g} / \mathrm{cc}$ greater than garnet and spinel peridotites over a pressure range extending up to $10 \mathrm{GPa}$ [Ducea and Saleeby, 1998b]. Such a density contrast would undoubtedly be greater for comparisons with peridotites containing inclusions of melt. We assert that an $\sim 35 \mathrm{~km}$ thick layer of garnet pyroxenite would be gravitationally unstable relative to the underlying lithospheric perodotite, as well as the deeper asthenosphere, and should ultimately sink into the underlying mantle. Such a density contrast is significantly greater than those compiled by O'Reilly et al. [2001] for lithospheric peridotites of vastly different ages and for shallow asthenosphere peridotites; contrasts implying the gravitational instability of cooled Phanerozoic lithosphere. Our analysis of the xenolith data leads us to conclude that nearly half of the subbatholith mantle lithosphere consisted of garnet pyroxenite, and the rest was peridotite that had yet to be extensively depleted (Figure 4). It follows that the subbatholith mantle lithosphere was highly susceptible to sinking relative to the underlying asthenosphere.

[45] A hypothetical representation of the mantle lithosphere drip and its replacement by asthenosphere is given in 


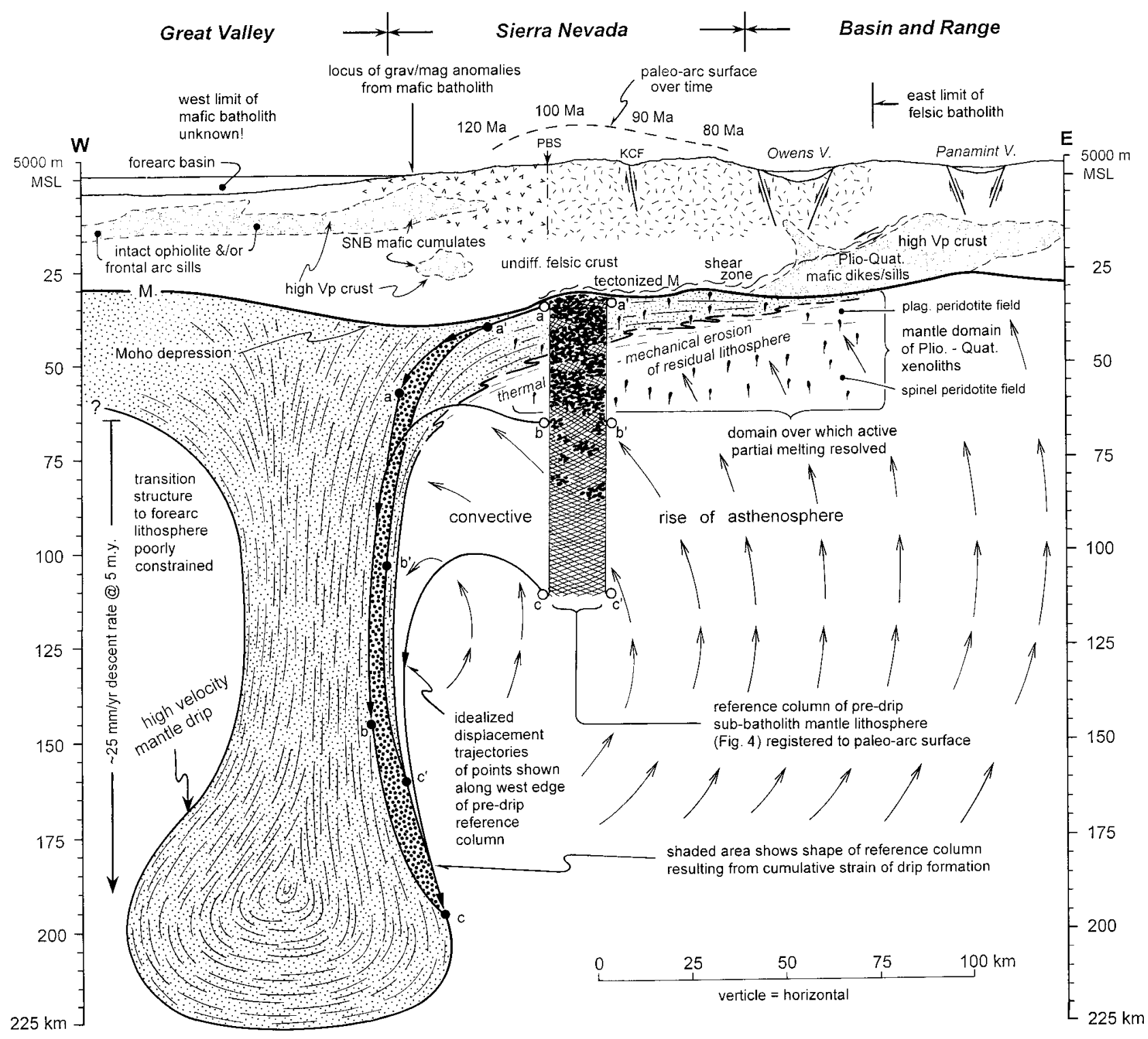

Figure 7. Section across the southern Sierra Nevada, adjacent Basin and Range province, and Great Valley along the trace of seismic refraction line presented by Ruppert et al. [1998] and Fliedner et al. [2000] showing synthesis of geological and geophysical data to a depth of $225 \mathrm{~km}$. The location of the section line is shown in Figure 1 (note that line extends $65 \mathrm{~km}$ farther west and $30 \mathrm{~km}$ farther east than shown in Figure 1). Lithologic patterns for the shallow batholith are the same as in Figure 1. Tectonized Moho and deep crustal shear zone beneath eastern Sierra-Owens Valley region are after Jones and Phinney [1998]; the partial melt in the upper mantle of the same region is after the same authors as well as Ducea and Saleeby [1996] and Park et al. [1996]. The high-velocity drip under the western Sierra region is modified after Zandt and Carrigan [1993], Jones et al. [1994], and Ruppert et al. [1998]. The shape of the drip and its internal flow and strain patterns are diagrammatic after Houseman et al. [2000] and are registered to the tomographic image published by Ruppert et al. [1998]. The reference column of the subbatholith mantle lithosphere in predrip position is taken from Figure 4. The paleoarc surface is constructed from batholith geobarometric and age data after Saleeby and Sharp [1980], Chen and Moore [1982], Ague and Brimhall [1988], and Clemens-Knott and Saleeby [1999]. The modeling of gravitymagnetic anomalies from exposed mafic complexes of Sierra Nevada batholith is after Oliver and Robbins [1982]. The quaternary normal slip on Kern Canyon fault (KCF) is after Nadin and Saleeby [2001]. 
Figure 7. The position and shape of the drip are based on the tomogram published by Ruppert et al. [1998], and the dynamic models presented in Houseman et al. [2000] and Jull and Keleman [2001]. The initial configuration of the subbatholith mantle lithosphere is depicted by a reference column based on Figure 4. This reference column is registered to the paleoarc surface along the axial region of the batholith. The column depicts the structure of the lithosphere beneath much of the crust along the cross section prior to its mobilization into the drip. Six open dots are shown along the edges of the reference column: at the top $\left(a, a^{\prime}\right)$ and bottom $\left(b, b^{\prime}\right)$ of the garnet pyroxenite complex, and at the base of the lithosphere $\operatorname{section}\left(\mathrm{c}, \mathrm{c}^{\prime}\right)$. The three dots along the western edge of the column ( $a, b$ and c) are tracked by displacement trajectories resulting from drip formation [after Houseman et al., 2000]. The corresponding positions of all six dots (filled solid) are shown in the drip structure. The shape of the reference column resulting from the cumulative strain of drip formation is shown by the shaded area within the drip. This analysis does not consider the possibility that the garnet pyroxenite layer accelerated relative to its lithosphere peridotite envelope during drip formation. Such a complex dynamic pattern seems likely given the aforementioned $\sim 0.2 \mathrm{~g} / \mathrm{cc}$ density contrast between the garnet pyroxenites and peridotites. Nor does this analysis consider the rheological contrasts between the garnet pyroxenite complex and the underlying lithosphere peridotite section.

[46] The rate at which the drip descended and the dynamic response of the ascending asthenosphere and residual crust are poorly understood. Most models of convective instability of the lower crust-upper mantle suggest significant responses at $10 \mathrm{~m} . \mathrm{y}$. timescales. We can offer some possible constraints on the temporal relations for the Sierra Nevada case. One early Late Miocene xenolith location in the central Sierra (8.6 Ma [Manley et al., 2000]) is aberrant in that it contains primarily high temperature spinel peridotites and is lacking garnet pyroxenites and garnet peridotites. This xenolith assemblage, as well as spinel peridotite xenoliths from one of the Pliocene locations contain silicic glass inclusions with trace element and isotopic characteristics suggestive of their derivation from partially melted labile accessory phases from the absent garnet pyroxenites [Ducea and Saleeby, 1998a]. The implications are that garnet pyroxenite descent and asthenospheric mantle ascent locally began by $8.6 \mathrm{Ma}$ (Late Miocene). Additionally, the analysis of Mio-Pliocene volcanism of the region [Ducea and Saleeby, 1998a; Manley et al., 2000; Farmer et al., 2002] relates a distinct compositional shift in erupted lavas to a broad domain of asthenospheric mantle that had ascended to the proximity of the crust by 3 to $4 \mathrm{Ma}$. Comparison of the centroid of the reference lithosphere to the centroid of the high-velocity core of the mantle drip (Figure 7) analyzed in the above temporal context leads to a hypothetical descent rate for the drip of $\sim 25 \mathrm{~mm} / \mathrm{yr}$. This rate is comparable to plate tectonic transport rates. The westward offset of the mantle drip from the axial region of the batholith requires attention if the source of the drip is to be related to the subbatholith residue complex. Modeling of convective instabilities [cf. Jull and Keleman, 2001] suggest that morphologic perturbations in the unstable layer can instigate and concentrate the growth of drip structures. We suggest that the overall more mafic composition of the western domain of the batholith including its underlying mantle lithosphere, may have served as such an initial perturbation resulting in the nucleation of the drip and the net westward flow of its contents. Dynamic modeling of such drip structures affecting the lithosphere predict a depression of the Moho over the drip [cf. Houseman et al., 2000]. As shown in Figure 7, such a Moho depression is clearly imaged by the seismic data [Ruppert et al., 1998; Fliedner et al., 2000]. The tectonized Moho resolved by Jones and Phinney [1998] beneath the eastern and axial Sierra may reflect traction along the base of the crust as the mobilized lithosphere moved westward into the drip. Inspection of Figure 7 shows that the drip is possibly also offset westward from the axis of the Moho depression. A possible explanation for this additional offset from the axis of the felsic batholith is partial entrainment of the drip into regional asthenosphere counterflow patterns [Zandt, 2003]. The surface response to the growth of the drip was the late Pliocene to Recent subsidence of a broad region centered over the drip which has imparted anomalous sediment "flooded" topography over mountainous regions of the southwestern Sierra, and the development of an internal subbasin within the southern Great Valley [Saleeby and Foster, 2003]. In regions to the east and northeast of the drip, where asthenosphere has replaced the convectively removed lithosphere, Pliocene to Recent uplift has occurred [cf. Crough and Thompson, 1977; Jones, 1987; Jones et al., 1994]. Possible out of section effects should be considered as well. Most accounts of the structure correlated to the drip recognize it as having a vertical cylindrical shape. Perhaps the drip gathered with along strike as well as across strike components of flow, relative to the regional strike of the batholith. In this regard it should also be pointed out that the highest concentration of surface level mafic-ultramafic cumulates of the entire exposed Sierra Nevada batholith is situated over the drip [Saleeby, 1981; Clemens-Knott and Saleeby, 1999].

[47] The asthenospheric mantle that has replaced the mantle lithosphere has a number of features suggesting that it has been locally hybridized or contaminated by lithospheric remnants. On the basis of teleseismic data Jones and Phinney [1998] point out the physical and likely compositional heterogeneity of the shallow asthenospheric mantle under the eastern Sierra region. The P-T field shown in Figure $2 \mathrm{~b}$ for Pliocene-Quaternary mantle xenoliths lies primarily along an asthenosphere adiabat [Ducea and Saleeby, 1996], but a few samples from one of the Quaternary locations are displaced modestly to the low $\mathrm{T}$ side of the adiabat [Lee et al., 2000, 2001]. Furthermore Nd, Sr and Os isotopic data on the Pliocene-Quaternary mantle xenoliths show wide isotopic heterogeneity ranging from modern asthenosphere to Proterozoic subcontinental lithosphere values [Beard and Glazner, 1995; Lee et al., 2000; Zeng et al., 2001a]. Likewise Pliocene-Quaternary basalts erupted in the region reveal such a heterogeneous mantle 
source regime [Van Kooten, 1981; Menzies et al., 1983; Beard and Glazner, 1995; Ducea, 1998; Farmer et al., 2002]. We assert, however, that the principal factor in the definition of asthenosphere is its physical state which is clearly defined for the Pliocene to Recent upper mantle beneath the southern Sierra region by the asthenospheric adiabat given on Figure $2 \mathrm{~b}$, as well as an array of seismic velocity studies [Ruppert et al., 1998; Jones and Phinney, 1998; Ji and Helmberger, 1999; Fliedner et al., 2000; Melbourne and Helmberger, 2001]. We suggest that much or all of the residual lithospheric mantle that was highly attenuated in the region beneath the axial and eastern Sierra during drip removal was thermally transformed to an asthenospheric physical state as the ascending asthenosphere sheared along its margin. Such thermal transformation may also have been accompanied by entrainment and commingling, and the advection of heat, fluids and labile chemical components by decompression partial melts. These processes together are shown on Figure 7 to have resulted in the thermal-mechanical erosion of the residual lithosphere beneath the eastern and axial Sierra. On the basis of geochemical data and total volume estimates of Pliocene volcanic rocks erupted through the central Sierra, Farmer et al. [2002] estimate a residual layer of lithospheric peridotite as thin as $\sim 1 \mathrm{~km}$ beneath the modern Moho. We assert however, that the geochemical signal of such erosion of the original subcontinental mantle lithosphere was cumulative and included the effects of Cretaceous mantle wedge influxes of asthenosphere as well as the effects of drip removal.

[48] Finally, we must ask how did the high-density garnet pyroxenite complex and the rest of the mantle lithosphere survive through much of Cenozoic time, and what triggered its removal between Late Miocene and Pliocene time? In a recent analysis of convective instabilities in the lower crust Jull and Kelemen [2001] argue for high Moho temperatures, and/or high regional strain rates for the initiation of drip structures. We suggest that conductive cooling of the greater Sierran lithosphere in Laramide and post-Laramide time, and a benign tectonic setting through mid-Cenozoic time within a broad forearc region left the high-density mantle lithosphere in a gravitationally metastable state. We further suggest that subsequent high-magnitude extension, that is well documented immediately east of the southern Sierra, was linked to the regional strain rate field that triggered the dynamics of the instability. Such extension progressed and accelerated from mid-Miocene to Pliocene time [Wernicke et al., 1988; Wernicke and Snow, 1998]. Critical to this analysis is the hypothesis set forth by Jones [1987], Wernicke [1992], Jones et al. [1994], and Jones and Phinney [1998] that highmagnitude extension in the adjacent Basin and Range was kinematically linked to the eastern Sierra via a deep normal sense crustal shear zone. Such a shear zone is shown on Figure 7 rooting beneath the eastern Sierra. High-velocity rocks along the lower plate of the shear zone are suggested here to have in part undergone extension by the emplacement of Pliocene-Quaternary mafic intrusives derived from the ascending asthenosphere. In our analysis Sierran mantle lithosphere drip formation, asthenosphere ascent and related magmatism, and high-magnitude extension to the east of the southern Sierra are essential components of a single integrated dynamic system.

\section{Discussion}

[49] The analysis offered above for late Cenozoic volcanic-hosted mantle xenoliths and geophysical data for the southern Sierra Nevada region, in conjunction with insights offered by the oblique crustal section offers an array of insights for topics ranging from the generation of the Sierra Nevada batholith and its lithospheric underpinnings to the Recent uplift of the range. We close with a discussion of some of these topics.

\subsection{Are Magmatism}

[50] Direct observations of the oblique crustal section of the southern Sierra Nevada batholith indicate that the crust has been completely reconstituted by batholith production to depths of at least $35 \mathrm{~km}$ [Saleeby, 1990]. Seismic studies performed across the shallow-level exposures to the north are consistent with this view [Jones and Phinney, 1998; Ruppert et al., 1998; Fliedner et al., 2000]. The xenolith data further indicate that the entire subbatholith mantle lithosphere was reconstituted in conjunction with batholith production. Nowhere in our sampling of the batholith lithospheric column is there evidence of a regionally extensive high-grade metamorphic terrane underlying the felsic batholith. Even the subordinate granulites are best explained as residues and/or cumulates produced by crystal-liquid equilibria related to batholith formation. Such large-scale reconstitution of a young continent-like lithospheric section raises questions regarding the relative proportions of juvenile mantle-derived components verses recycled continental components.

[51] Isotopic studies of the Sierra Nevada batholith typically call for subequal amounts of juvenile mantle-derived material and recycled crustal material for the batholith material budget [Kistler and Peterman, 1973; DePaolo, 1981; Saleeby et al., 1987; Kistler, 1990; Chen and Tilton, 1991; Pickett and Saleeby, 1994]. The involvement of enriched subcontinental mantle lithosphere in the mantle wedge source reduces the relative amount of crustal recycling needed to satisfy the isotopic data [Coleman et al., 1992; Sisson et al., 1996; Coleman and Glazner, 1998]. However, $\mathrm{Sr}-\mathrm{Nd}$ and $\mathrm{Pb}-\mathrm{Pb}$ isotopic variation patterns for the felsic batholith and the garnet pyroxenite complex indicate a nontrivial component of lower continental crustal materials in the eastern domain [Chen and Tilton, 1991; Ducea and Saleeby, 1998a; Ducea, 1998, 2001; Zeng et al., 2001b]. Furthermore, Sr-O isotopic variation patterns for parts of both the eastern and western domains indicate a nontrivial component of continent-derived sediment in the material budget [DePaolo, 1981; Saleeby et al., 1987; Kistler, 1990; Clemens-Knott et al., 1991; Clemens-Knott, 1992; Lackey et al., 2002]. Thus for much of the felsic batholith recycled continental crustal components were a nontrivial part of the material budget. In terms of the bulk composition of the batholith plus its residues, the reconstructed lithospheric 
Table 1. Averaged Major Element Abundances

\begin{tabular}{lccr}
\hline & $\begin{array}{c}\text { Sierran Garnet } \\
\text { Clinopyroxenite } \\
\text { Xenoliths }\end{array}$ & $\begin{array}{c}\text { a } \\
\text { Granitoids of the Central } \\
\text { Sierra Nevada Batholith }\end{array}$ & 1:1 Mixture \\
\hline $\mathrm{SiO}_{2}$ & 44.78 & 64.90 & 54.84 \\
$\mathrm{TiO}_{2}$ & 1.29 & 0.56 & 0.93 \\
$\mathrm{Al}_{2} \mathrm{O}_{3}$ & 13.21 & 16.61 & 14.91 \\
$\mathrm{FeO}^{\mathrm{c}}$ & 12.73 & 4.70 & 8.71 \\
$\mathrm{MgO}$ & 11.78 & 2.25 & 7.01 \\
$\mathrm{CaO}$ & 12.93 & 4.34 & 8.63 \\
$\mathrm{NaO}$ & 1.24 & 3.34 & 2.29 \\
$\mathrm{~K}$ & 0.27 & 2.25 & 1.26 \\
\hline
\end{tabular}

${ }^{\mathrm{a}}$ From Ducea [1998].

${ }^{b}$ From Bateman and Dodge [1970].

${ }^{\mathrm{c}}$ Total Fe.

column of Figure 4 in conjunction with elemental abundance data offer some constraints. Table 1 shows averaged major element abundances of Sierran garnet clinopyroxenite xenoliths [Ducea, 1998], and granitoids of the central Sierra Nevada batholith [Bateman and Dodge, 1970]. Inspection of the Figure 4 column reveals subequal amounts of the garnet pyroxenite complex and the overlying felsic batholith. The computed average of such a 1:1 mixture yields a high$\mathrm{Mg}$ basaltic-andesite. A slightly more mafic bulk composition is conceivable by factoring in the subordinate granulite layer in the mixture, and by considering the possible early stage loss of garnet pyroxenite drips into and through the underlying peridotitic wedge (Figure 5).

[52] If we consider the entire Cretaceous batholith, however, the bulk composition becomes considerably more mafic. The western domain of the batholith, including a substantial tract of plutonic rocks known only from basement cores and geophysical data beneath the Great Valley [Saleeby and Williams, 1978; Saleeby, 1981; Oliver and Robbins, 1982] is routinely ignored in the literature when various workers consider the material budget of the batholith. Between Latitudes $36^{\circ}$ and $37^{\circ} \mathrm{N}$ there is a well-exposed belt of intrusives that are typical of those found beneath the Valley (westernmost domain) whose structure and petrology offer insights into Early Cretaceous batholithic magmatism. Here a series of well-exposed ring dike complexes that developed over $\sim 5$ m.y. time intervals show similar petrogenetic patterns which are typical of the entire exposure belt, which may contain remnants of other disrupted ring dike complexes [Mack et al., 1979; Saleeby and Sharp, 1980; Clemens-Knott and Saleeby, 1999]. Each starts with the emplacement of voluminous olivine-bearing hydrous mafic and ultramafic cumulates followed by well defined crescent to ring-shaped dikes of gabbronorite and pyroxene quartz gabbrodiorite. They appear to be the roots of long-lived basalt-andesite volcanic centers [cf. Clemens-Knott and Saleeby, 1999; Clemens-Knott et al., 2000]. Sedimentary petrofacies data for the Lower Cretaceous interval of the Great Valley forearc sequence reveal copious detritus derived form such a mafic arc [Dickinson and Rich, 1972]. The Early Cretaceous Sierra Nevada batholith was primarily mafic, similar to intro-oceanic arcs, with the principal controlling factors being its generation within a depleted mantle source regime [Kistler and Peterman, 1973; Saleeby and Sharp, 1980; Clemens-Knott et al., 1991; ClemensKnott, 1992], and its ascent through oceanic lithosphere that had been sutured against North American lithosphere and trapped above the Cretaceous subduction zone [Saleeby, 1981]. The western extent of such mafic batholithic rocks beneath the Great Valley is unknown. Such rocks are abundantly represented in basement cores from the axial regions of the northern Great Valley where they occur in association with gravity-magnetic anomalies [Saleeby and Williams, 1978], and in the southwest Sierra Foothills they are shown to be the principal source of such anomalies [Oliver and Robbins, 1982]. High-velocity midcrustal rocks that extend across the axial southern Great Valley could be in large part composed of such mafic rocks (Figure 7). It is a common mistake in the literature to designate such mafic batholithic rocks of the Great Valley as part of the ophiolitic basement [cf. Godfrey and Klemperer, 1998]. It is not unreasonable to speculate that a substantial proportion of the $\sim 30 \mathrm{~km}$ thick crust of the axial and eastern Great Valley was constructed by Early Cretaceous mafic arc plutonism. The crustal thickness and velocity structure of the Great Valley do not resemble that of an intact ophiolite even though the metamorphic framework for the mafic batholithic rocks consists primarily of ophiolitic rocks.

\subsection{Loss of the Lower Crust}

[53] Considerable discussion has been focused on the delamination or convective removal of subcontinental mantle lithosphere [Bird, 1979, 1988; Conrad and Molnar, 1997; Houseman and Molnar, 1997b], and there seems to be a consensus that the Phanerozoic subcontinental mantle lithosphere in particular is susceptible to such attrition in geologic time [O'Reilly et al., 2001]. The mechanisms and importance of lower-crustal loss seem to have gained less of a consensus [Dewey et al., 1993; Kay and Kay, 1991, 1993; Jull and Kelemen, 2001; Leech, 2001]. Most discussions of lower-crustal loss focus on the transition of crustal rocks to eclogite facies metamorphic assemblages, particularly in collisional orogenic belts. Concerns have been raised over the extent of the eclogite conversion due to sufficient fluid activities, kinetic effects of protolith grain size distributions, and the involvement of retrograde reactions to lower-density assemblages. Overstepping of eclogite facies reaction boundaries in exhumed ultra-high-pressure metamorphic terranes of as much as $1 \mathrm{GPa}$ have been documented as well [Austrheim, 1998]. Jull and Keleman [2001] have also discussed the potential for the convective instability and removal of a thick accumulation of mafic arc rocks relative to peridotitic mantle. They elude to the solid-state conversion of deep-level cumulates to eclogite. However, the course grain size of such deep gabbroids, a limited fluid budget, a declining thermal gradient, as well a possible lack of high regional strain rates would work against pervassive eclogite conversion in such an environment [cf. Hacker, 1996; Austrheim, 1998; Leech, 2001].

[54] We provide evidence for a mantle lithosphere and lower "crustal" removal mechanism that is significantly different from the mechanisms referred to above. The 
production of a thick garnet pyroxenite residue complex in the source regime of a long-lived magmatic arc is conceivably a much more effective mechanism for the production of a high-density "crustal" root than the conversion of crustal rock sequences to eclogite facies metamorphic assemblages by crustal thickening. The segregation of garnet + pyroxene residues from felsic magmas by crystal-liquid equilibria is a much more effective mechanism for producing very high-density crustal affinity rocks than the eclogite solid state transition. Segregation and migration of the felsic melt upward and out of the system is conceivably a near complete process, which is consistent with a lack of felsic inclusions within the garnet pyroxenite xenoliths. Furthermore, the dilution of the hydrous mafic source by preexisting felsic crustal components results in higher felsic melt fractions with the same high-density residue assemblage, at given pressure conditions. This is born out in the types of theoretical calculations shown in Figure 3 as well as by experimental data [Carroll and Wyllie, 1990]. These observations and considerations are in sharp contrast to what is observed and what is to be expected in orogenically thickened continental crust. In such settings a diverse suite of protolith assemblages are introduced into the deep crustal metamorphic environment thereby producing an array of densities for which only the mafic endmember metamorphic products could match the high-density garnet pyroxenite residue assemblage. The aforementioned concerns of complete eclogite transformation further undermine the density increase upon tectonic thickening. Finally, the crystal-liquid fractionation process of garnet pyroxenite production differentiates the crust into a well-defined upper felsic batholithic layer and an underlying high-density residue layer. Orogenic thickening will be less effective in its mechanical segregation, and in conjunction with the varied protolith and incomplete transformation effects will yield a broad integrated gradient of increasing lower crustal densities with possible significant density inversions.

[55] We reiterate that the removal of the garnet pyroxenite complex and underlying peridotite section was at essentially the same structural level by both mechanical delamination during Laramide flat slab subduction in the southernmost Sierra, and by convective instability during the onset of late Neogene Basin and Range extension in the greater Sierra Nevada region to the north. We suggest that the pronounced depth-dependent density contrast between the garnet pyroxenites and the overlying felsic batholith in conjunction with the greater strength of the garnet + pyroxene aggregate [ $\mathrm{Ji}$ and Martignole, 1994; Kollé and Blacic, 1983] as compared to the probable fluid present deep felsic crust [Tullis and Yund, 1977] provided an ideal separation horizon upon the onset of suitable superimposed regional strain rates.

[56] The reconstructed Sierra Nevada batholith lithospheric column of Figure 4 shows a pronounced transition between 35 and $45 \mathrm{~km}$ depth from felsic batholithic assemblages through mafic granulites to the garnet pyroxenite complex. The position of the plagioclase out line and its relationship to the partial melting of water present crustal rocks suggests that large volume felsic batholiths should not extend to depths greater that 40-45 km. Christensen and
Mooney [1995] report that most inactive Phanerozoic continental arcs exhibit a typical 30 to $40 \mathrm{~km}$ depth to the Moho. This can be explained by the phase relations exhibited in Figure 2a with both the experimental data and the xenolith thermobarometric data. First, as stated above, the plagioclase out boundary limits the depth interval over which large volume felsic batholiths can form. And then subsequently the loss of the underlying mantle lithosphere by delamination or convective removal will fall in a comparable depth interval as a result of the density, and rheologic contrasts discussed above. Such localization of the separation of batholithic crust from its residue complex accentuates the fractionation and survival of large-volume felsic batholiths through geologic time.

\subsection{Sierran Uplift}

[57] A once long-standing interpretation for the support of the 3000 to $4000 \mathrm{~m}$ high Sierra Nevada was the existence of a low-density Airy crustal root for the batholith [Bateman and Eaton, 1967]. This was brought into question by Crough and Thompson [1977] and Jones [1987] who argued for an upper mantle support mechanism. Such a crustal root is now shown clearly not to exist by seismic studies [Jones and Phinney, 1998; Ruppert et al., 1998; Fliedner et al., 2000]. The xenolith data add "ground truth" to these seismic studies in two senses: (1) the root for the Sierra Nevada batholith was primarily high-density garnet pyroxenite and (2) Recent asthenosphere peridotites extend upward to the base of the crust at 30-35 km depths. A contrast of $\sim 0.2 \mathrm{~g} / \mathrm{cc}$ is representative of the approximate density difference between the garnet pyroxenite xenoliths and typical mantle peridotite. Using a "mantle Pratt" compensation model for support of the modern range [cf. Jones et al., 1994], the convective replacement of the $\sim 35 \mathrm{~km}$ thick garnet pyroxenite layer and its underlying peridotitic section by asthenospheric mantle could yield an uplift response of $\sim 2500 \mathrm{~m}$. Since loss of the high-density root occurred in conjunction with regional high-magnitude extension such an uplift response must be weighed against possible crustal thinning in considering late Cenozoic net elevation change [cf. House et al., 1997a]. Loss of $\sim 20 \mathrm{~km}$ of middle to lower felsic crust by thinning could balance the removal of the garnet pyroxenite complex. Considering roughly $5-8 \mathrm{~km}$ of erosion of the batholith along the Sierran crest, based on igneous barometry patterns (Figure 1), in conjunction with the phase relations summarized in Figure 2a, it appears that no more than 5-10 km of crustal thinning could have effected the Sierra crest region with the survival of the batholithic crustal section imaged by the seismic data (Figure 7). This suggests that removal of the subbatholith mantle lithosphere in conjunction with high-magnitude extension could have generated a net elevation increase of as much as $1000-1500 \mathrm{~m}$.

[58] The dynamic response of Sierran uplift to the loss of its mantle lithosphere and the ascent of asthenospheric mantle are at a 5 m.y. timescale. In contrast, conductive cooling of continental lithosphere occurs at a 100 m.y. timescale. Heat flow measurements for the Sierra Nevada 
are at the low range for continental regions [Saltus and Lachenbruch, 1991]. It is suggested that the modern surface heat flow signal is that of the Laramide orogeny instigated conductive cooling. Furthermore, seismicity in the southern Sierra Nevada extends nearly to the Moho suggesting a relatively cool, brittle felsic crustal section [Wong and Savage, 1983; Miller and Mooney, 1994]. This suggests that the thermal signal from the late Miocene-Pliocene lithosphere removal event has yet to propagate very far into the deep Sierran crust. This is consistent with the two different timescales at which convective removal dynamics verses heat conduction work.

\section{Conclusions}

[59] Recent experimental studies on the melting of hydrous mafic to intermediate composition assemblages in the 1 to $3 \mathrm{GPa}$ range indicate that felsic magma production renders a residue rich in garnet and clinopyroxene. Isotopic and petrogenetic studies of garnet clinopyroxenite xenoliths entrained in mid-Miocene volcanic centers from the central Sierra Nevada batholith indicate that they are coeval and cogenetic with the overlying felsic batholith, and that they represent residues left from the partial melting of principally hydrous mafic assemblages. The deepest-level exposures of the Sierra Nevada batholith are part of a southward deepening oblique crustal section which reaches $\sim 1$ GPa conditions. The batholith is structurally continuous and dominantly felsic to these deep levels, and its structure indicates complete reconstitution of the crust by composite batholith formation. Within the deep-level exposures a number of hydrous mafic cumulate bodies exhibit local remelting with the production of tonalitic melts and garnet rich residues. Furthermore, such hydrous mafic cumulates are a ubiquitous part of the batholith, at all structural levels, in various proportions. From these observations, it is suggested that large volume felsic magmas of the batholith, and conceivably other Cordilleran-type batholithic belts, are produced by a two-stage process initiating with mantle wedge-derived hydrous mafic magmatism above subducting oceanic lithosphere. As hydrous mafic cumulates form and thicken at lower crust-upper mantle levels, along with enclaves of preexisting crustal rocks, they ultimately undergo remelting induced by hornblende breakdown and liberation of water to generate felsic batholithic magmas and garnet clinopyroxenite residues. Garnet clinopyroxenite xenolith thermobarometric data suggest that a $\sim 35 \mathrm{~km}$ thick residue "root" formed beneath the batholith in Cretaceous time. This root is petrogenetically crustal rock but seismically mantle rock. Upon cooling the high-density root formed the upper $\sim 35 \mathrm{~km}$ of the subbatholith mantle lithosphere which was floored by mantle wedge peridotite. The peridotites rendered xenoliths with equilibration pressures corresponding to depths as much as $\sim 125 \mathrm{~km}$. The mantle xenolith data along with the oblique crustal section data further reveal that the entire lithosphere of the Sierra Nevada was reconstituted in conjunction with batholith production.

[60] Garnet clinopyroxenite constituted a significant component of the Sierran mantle lithosphere both as a concentrated upper layer and as enclaves in the underlying wedge peridotite section. These garnet-rich rocks are of the order of $0.2 \mathrm{~g} / \mathrm{cc}$ denser than typical mantle peridotite. Consequently their high concentration in the mantle lithosphere rendered the lithosphere gravitationally unstable relative to asthenospheric mantle. At least two mantle lithosphere removal events occurred in the southern Sierra Nevada region. First, during the Laramide orogeny it was mechanically delaminated in the southernmost Sierra and adjacent Mojave Desert region by shallow-level flat slab subduction, and replaced by underthrust subduction accretion assemblages. Then in late Neogene time, in the greater Sierra Nevada to the north, the subbatholith lithosphere that survived the Laramide orogeny was convectively removed in association with high-magnitude Basin and Range extension immediately to the east. Garnet pyroxenites and peridotites of the subbatholith mantle lithosphere survived in the central Sierra Nevada region until their mid-Miocene entrainment as xenoliths in the deeply derived host lavas. This in conjunction with the removal of such rocks farther south by Laramide tectonics suggests that the Laramide slab was segmented into a shallow segment to the south and a deeper segment to the north. The main expression of Laramide flat slab subduction to the north appears to be the termination of arc magmatism and conductive cooling of the subarc mantle wedge to a lithosphere conductive geotherm. It is suggested that this resulted principally by the flat slab disrupting the corner flow pattern which kept the wedge environment fertile and hot, a necessary condition for prolonged arc magmatism. Termination of batholithic magmatism over the shallow slab segment to the south entailed the mechanical disruption and removal of the entire magma source regime.

[61] The transition from felsic batholithic materials to high-density residues between 35 and $45 \mathrm{~km}$ depths provides a primary rheological boundary for mantle lithosphere removal to occur along. Both subbatholithic mantle lithosphere removal events in the southern Sierra Nevada region occurred along this boundary despite the contrasting attendant tectonic environments. Many batholithic belts around the world render 30 to $40 \mathrm{~km}$ crustal thicknesses. It is suggested that the processes described above for the production and loss of the high-density residue complex for the Sierra Nevada batholith are globally important for continent edge arcs, and that such processes working over geologic time both chemically and mechanically fractionate and isolate felsic crust at the earth's surface. The sinking of garnet-rich residues from deep crustal magmatic systems into the mantle also provides a mechanism for returning crustal chemical components and isotopic signatures to the mantle.

[62] Acknowledgments. Support for this work was provided by NSF grants EAR-9526859, EAR-9815024, and EAR-0087347 (Saleeby) and EAR-0087125 (Ducea). Discussions and field excursions with L. T. Silver, R. W. Kistler, D. L. Anderson, P. D. Asimow, M. Gurnis, D. Helmberger, C. T. Lee, M. B. Wolf, P. J. Wyllie, G. Zandt, L. Zeng, and the entire Southern Sierra Continental Dynamics Project working group helped stimulate this work. Critical reviews from Peter Molnar and an unidentified reviewer are gratefully acknowledged. Drafting and technical assistance from Zorka Foster is gratefully acknowledged. Assistance in manuscript preparation by Kim Klotz is kindly acknowledged. 


\section{References}

Ague, J. J., Thermodynamic calculation of emplacement pressures for batholithic rocks, California: Implication for the aluminum-in-hornblende barometer, Geology, 25, 563-566, 1997.

Ague, J. J., and G. H. Brimhall, Magmatic arc asymmetry and distribution of anomalous plutonic belts in the batholiths of California: Effects of assimilation, crustal thickness, and depth of crystallization, Geol. Soc. Am. Bull., 100, 912-927, 1988.

Asimow, P. D., Steady-state mantle-melt interactions in one dimension: II. Thermal interactions and irreversible terms, J. Petrol., 43, 1707-1724, 2002.

Austrheim, H., Influence of fluid and deformation on metamorphism of the deep crust and consequences for the geodynamics of collision zones, in When Continents Collide: Geodynamics and Geochemistry of Ultrahigh-Pressure Rocks, edited by B. R. Hacker and J. G. Liou, pp. 297-323, Kluwer Acad., Norwell, Mass., 1998.

Barazangi, M., and B. Isacks, Spatial distribution of earthquakes and subduction of the Nazca plate beneath South America, Geology, 4, 686-692, 1976.

Basaltic Volcanism Study Project, Basaltic Volcanism in the Terrestrial Planets, Pergamon, New York, 1981.

Bateman, P. C., and F. C. W. Dodge, Variations of major chemical constituents across the central Sierra Nevada batholith, Geol. Soc. Am. Bull., 81, 409-420, 1970.

Bateman, P. C., and J. P. Eaton, Sierra Nevada batholith, Science, 158, 1407-1417, 1967.

Beard, B. L., and A. F. Glazner, Trace element and Sr and $\mathrm{Nd}$ isotopic composition of mantle xenoliths from the Big Pine volcanic field, California, J. Geophys. Res., 100, 4169-4179, 1995.

Billen, M. I., and M. Gurnis, A low viscosity wedge in subduction zones, Earth Planet. Sci. Lett., 193, $227-236,2001$.

Bird, P., Continental delamination and the Colorado Plateau, J. Geophys. Res., 84, 7561-7571, 1979.

Bird, P., Formation of the Rocky Mountains, western United States: A continuum computer model, Science, 239, 1501-1507, 1988 .

Carroll, M. R., and P. J. Wyllie, The system tonalite$\mathrm{H}_{2} \mathrm{O}$ at $15 \mathrm{kbar}$ and the genesis of calc-alkaline magmas, Am. Mineral., 75, 345-357, 1990.

Cheadle, M. J., B. L. Czuchra, T. Byrne, C. J. Ando, J. E. Oliver, L. D. Brown, S. Kaufman, P. E. Malin, and R. A. Phinney, The deep crustal structure of the Mojave Desert, California, from COCORP seismic reflection data, Tectonics, 5, 293-320, 1986.

Chen, J. H., and J. G. Moore, Uranium-lead isotopic ages from the Sierra Nevada batholith, J. Geophys. Res., 87, 4761-4784, 1982

Chen, J. H., and G. R. Tilton, Applications of lead and strontium isotopic relationships to the petrogenesis of granitoid rocks, central Sierra Nevada batholith, California, Geol. Soc. Am. Bull., 103, 439-447, 1991.

Christensen, N. I., and W. D. Mooney, Seismic velocity structure and composition of the continental crust: A global review, J. Geophys. Res., 100, 9761 9788, 1995.

Clemens-Knott, D., Geologic and isotopic investigations of the Early Cretaceous Sierra Nevada batholith, Tulare Co, CA and the Ivrea zone, NW Italian Alps: Examples of interaction between mantle derived magmas and continental crust, Ph.D. thesis, 349 pp., Calif. Inst. of Technol., Pasadena, 1992.

Clemens-Knott, D., Neodymium isotope constraints on the character of the central Sierra Nevada deep crus and upper mantle: Chinese Peak xenoliths (abstract), Geol. Soc. Am. Abstr. Prog., 28, 56, 1996.

Clemens-Knott, D., and J. B. Saleeby, Impinging ring dike complexes in the Sierra Nevada batholith, California: Roots of the Early Cretaceous volcanic arc, Geol. Soc. Am. Bull., 111, 484-496, 1999.

Clemens-Knott, D., J. B. Saleeby, and H. P. Taylor Jr., $\mathrm{O}, \mathrm{Sr}$ and $\mathrm{Nd}$ constraints on the evolution of the
Early Cretaceous Sierra Nevada batholith (abstract), Geol. Soc. Am. Abstr. Prog., 23, 386, 1991.

Clemens-Knott, D., M. B. Wolf, and J. B. Saleeby, Middle Mesozoic plutonism and deformation in the western Sierra Nevada foothills, California, Geol. Soc. Am. Field Guide, 2, 205-221, 2000.

Coleman, D. S., and A. F. Glazner, The Sierra cres magmatic event: Rapid formation of juvenile crust during the late Cretaceous in California, in Integrated Earth and Environmental Evolution of the Southwestern United States, edited by W. G. Erns and C. A. Nelson, pp. 253-272, Bellwether, Columbia, Md., 1998

Coleman, D. S., T. P. Frost, and A. F. Glazner, Evidence from the Lamarck Granodiorite for rapid Late Cretaceous crust formation in California, Science, 258, 1026-1924, 1992.

Coney, P. J., and S. J. Reynolds, Cordilleran Benioff zones, Nature, 270, 403-406, 1977.

Conrad, C. P., and P. Molnar, The growth of RayleighTaylor-type instabilities in the lithosphere for various rheological and density structures, Geophys. $J$ Int., 129, 95-112, 1997.

Crough, S. T., and G. A. Thompson, Upper mantle origin of Sierra Nevada uplift, Geology, 5, 396399, 1977.

DePaolo, D. J., A neodymium and strontium isotopic study of the Mesozoic calc-alkaline granitic bath oliths of the Sierra Nevada and Peninsular Ranges, California, J. Geophys. Res., 86, 10,470-10,488, 1981.

Dewey, J. F., P. D. Ryan, and T. B. Andersen, Orogenic uplift and collapse, crustal thickness, fabrics and metamorphic phase changes: The role of eclogites, Geol. Soc. Am. Spec. Publ., 76, 325-343, 1993

Dickinson, W. R., and E. I. Rich, Petrologic intervals and petrofacies in the Great Valley Sequence, Sacramento Valley, California, Geol. Soc. Am. Bull., 83, 3007-3024, 1972

Dickinson, W., and W. S. Snyder, Plate tectonics of the Laramide orogeny, Geol. Soc. Am. Mem., 151, 335-366, 1978.

Dixon, E. T., ${ }^{40} \mathrm{Ar} /{ }^{39} \mathrm{Ar}$ hornblende geochronology and evaluation of garnet and hornblende barometry, Lake Isabella to Tehachapi area, southern Sierra Nevada, California, M.S. thesis, 63 pp., Univ. of Mich., Ann Arbor, 1995.

Dodge, F. C. W., L. C. Calk, and R. W. Kistler, Lower crustal xenoliths, Chinese Peak lava flow, Centra Sierra Nevada, J. Petrol., 27, 1277-1304, 1986.

Dodge, F. C. W., J. P. Lockwood, and L. C. Calk, Fragments of the mantle and crust beneath the Sierra Nevada batholith: Xenoliths in a volcanic pipe near Big Creek, California, Geol. Soc. Am. Bull., 100, 938-947, 1988

Domenick, M. A., R. W. Kistler, F. C. W. Dodge, and M. Tatsumoto, Nd and $\mathrm{Sr}$ isotopic study of crusta and mantle inclusions from beneath the Sierr Nevada and implications for batholith petrogenesis, Geol. Soc. Am. Bull., 94, 713-719, 1983.

Ducea, M. N., A petrologic investigation of deep-crustal and upper-mantle xenoliths from the Sierr Nevada, California: Constraints on lithospheric composition beneath continental arcs and the origin of Cordilleran batholiths, Ph.D. thesis, 473 pp. Calif. Inst. of Technol., Pasadena, 1998.

Ducea, M. N., The California arc: Thick granitic batholiths, ecogitic residues, lithospheric-scale thrusting, and magmatic flare-ups, GSA Today, 11, 410,2001

Ducea, M. N., and J. B. Saleeby, Buoyancy sources for a large, unrooted mountain range, the Sierra Nevada, California: Evidence from xenolith thermobarometry, J. Geophys. Res., 101, 8229-8244, 1996.

Ducea, M. N., and J. B. Saleeby, The age and origin of a thick mafic-ultramafic keel from beneath the Sierra Nevada Batholith, Contrib. Mineral. Petrol., 133, $169-185,1998$ a
Ducea, M. N., and J. B. Saleeby, A case for delamination of the deep batholithic crust beneath the Sierra Nevada, California, Int. Geol. Rev., 133, 78-93, $1998 b$

Ducea, M. N., and J. B. Saleeby, Crustal recycling beneath continental arcs: Silica-rich glass inclusions in ultramafic xenoliths from the Sierra Nevada, California, Earth Planet. Lett., 156, 101 - 116, 1998c.

Dumitru, T. A., Subnormal Cenozoic geothermal gradients in the extinct Sierra Nevada magmatic arc: Consequences of Laramide and post-laramide shallow-angle subduction, J. Geophys. Res., 95, 4925 4941, 1990.

Dumitru, T. A., P. B. Gans, D. A. Foster, and E. L. Miller, Refrigeration of the western Cordilleran lithosphere during Laramide shallow-angle subduction, Geology, 19, 1145-1148, 1991.

Elliott, T., T. Plank, A. Zindler, W. White, and B. Bourdon, Element transport from slab to volcanic front at the Mariana arc, J. Geophys. Res., 102, $14,991-15,019,1997$

Evernden, J. F., and R. W. Kistler, Chronology of emplacement of Mesozoic batholithic complexe in California and western Nevada, U.S. Geol. Surv. Prof. Pap., 623, 42 pp., 1970.

Farmer, L. G., A. F. Glazner, and C. R. Manley, Did lithosphere delamination trigger late Cenozoic potassic volcanism in the southern Sierra Nevada, California?, Geol. Soc. Am. Bull., 114, 754-768, 2002

Fiske, R. S, and O. T. Tobisch, Middle Cretaceous ashflow tuff and caldera-collapse deposit in the Minarets Caldera, east-central Sierra Nevada, California, Geol. Soc. Am. Bull., 106, 582-593, 1994.

Fliedner, M. M., S. L. Klemperer, and N. I. Christensen, seismic model of the Sierra Nevada arc, California, and its implications for crustal and upper mantle composition, J. Geophys. Res., 105, 10,89910,921, 2000.

Ghiorso, M. S., and R. O. Sack, Chemical mass transfer in magmatic processes, IV, A revised and internally consistent thermodynamic model for the interpolation and extrapolation of liquid-solid equilibria in magmatic systems at elevated temperatures and pressures, Contrib. Mineral. Petrol., 119, $197-$ 212, 1995.

Godfrey, N. J., and S. L. Klemperer, Ophiolitic basement to a forearc basin and implications for continental growth: The Coast Range/Great Valley ophiolite, California, Tectonics, 17, 558-570, 1998 .

Graeber, F. M., and G. Asch, Three-dimensional models of $P$ wave velocity and $P$-to- $S$ velocity ratio in the southern central Andes by simultaneous inversion of local earthquake data, J. Geophys. Res., 104, 20,237-20,256, 1999

Gromet, L. P., and L. T. Silver, REE variations across the Peninsular Ranges batholith: Implications for batholithic petrogenesis and crustal growth in magmatic arcs, J. Petrol., 28, 75-125, 1987.

Gutscher, M.-A., W. Spakman, H. Bijwaard, and E. R. Engdahl, Geodynamics of flat subduction: Seismicity and tomographic constraints from the Andean margins, Tectonics, 19, 814-833, 2000.

Hacker, B. R., Eclogite formation and the rheology, buoyancy, seismicity, and $\mathrm{H}_{2} \mathrm{O}$ content of oceanic crust, in Subduction: Top to Bottom, Geophys. Monogr. Ser, vol. 96, edited by G. E. Bebout et al., pp. 337-346, AGU, Washington, D. C., 1996

Hall, P. S., and C. Kincaid, Diapiric flow at subduction zones: A recipe for rapid transport, Science, 292, $2472-2475,2001$

House, M. A., B. P. Wernicke, K. A. Farley, and T. A Dumitru, Cenozoic thermal evolution of the central Sierra Nevada, California, from (U-Th)/He thermochronometry, Earth Planet. Sci. Lett., 151, 167179, 1997.

House, M. A., B. P. Wernicke, and K. A. Farley, Paleogeomorphology of the Sierra Nevada, California 
from (U-Th)/He ages in apatite, Am. J. Sci., 301, $77-102,2001$

Houseman, G. A., and P. Molnar, Gravitational (Rayleigh-Taylor) instability of a layer with non-linear viscosity and convective thinning of continental lithosphere, Geophys. J. Int., 128, 125-150, 1997.

Houseman, G. A., E. A. Neil, and M. D. Kohler, Lithospheric instability beneath the Transverse Ranges of California, J. Geophys. Res., 105, 16,237-16,250, 2000.

Jacobson, C. E., Qualitative thermobarometry of inverted metamorphism in the Pelona and Rand schists, southern California, using calciferous amphibole in mafic schists, J. Metamorph. Geol., 13, 79-92, 1995

Jacobson, C. E., F. R. Oyarzabal, and G. B. Haxel, Subduction and exhumation of the Pelona-Orocopia-Rand schists, southern California, Geology, 24, $547-550,1996$.

Ji, C., and D. V. Helmberger, Uppermost mantle structure cross the southern Sierra Nevada (abstract), Eos Trans. AGU, 80(46), Fall Meet. Suppl., F173, 1999.

Ji, S., and J. Martignole, Ductility of garnet as an indicator of extremely high temperature deformation, J. Struct. Geol., 16, 985-996, 1994.

Jones, C. H., Is extension in Death Valley accommodated by thinning of the mantle lithosphere beneath the Sierra Nevada, California?, Tectonics, 6, 449473, 1987

Jones, C. H., and R. A. Phinney, Seismic structure of the lithosphere from teleseismic converted arrivals observed at small arrays in the southern Sierra Nevada and vicinity, California, J. Geophys. Res., 103, 10,065-10,090, 1998 .

Jones, C. H., H. Kanimori, and S. W. Roecker, Missing roots and mantle "drips": Regional $P_{n}$ and teleseismic arrival times in the southern Sierra Nevada and vicinity, California, J. Geophys. Res., 99, 45674601, 1994.

Jordan, T. E., B. L. Isacks, R. W. Allmendinger, J. A Brewer, V. A. Ramos, and C. J. Ando, Andean tectonics related to geometry of subducted Nazca plate, Geol. Soc. Am. Bull., 94, 341-361, 1983.

Jull, M., and P. B. Kelemen, On the conditions for lower crustal convective instability, J. Geophys. Res., 106, 6423-6446, 2001

Kay, R. W., and S. M. Kay, Creation and destruction of the lower continental crust, Geol. Rundsch., 80, 259-270, 1991.

Kay, R. W., and S. M. Kay, Delamination and delamination magmatism, Tectonophysics, 219, 177-189, 1993.

Kistler, R. W., Two different types of lithosphere in the Sierra Nevada, California, Geol. Soc. Am. Mem., 174, 271-282, 1990.

Kistler, R. W., and Z. Peterman, Variations in $\mathrm{Sr}, \mathrm{Rb}, \mathrm{K}$, $\mathrm{Na}$ and initial ${ }^{87} \mathrm{Sr} /{ }^{86} \mathrm{Sr}$ in Mesozoic granitic rocks and intruded wall rocks in central California, Geol. Soc. Am. Bull., 84, 3489-3512, 1973.

Kollé, J. J., and J. D. Blacic, Deformation of singlecrystal clinopyrozenes: 2. Dislocation-controlled flow processes in hedenbergite, J. Geophys. Res., $88,2381-2393,1983$.

Lackey, J. S., J. W. Valley, and J. Saleeby, Evidence from zircon for high-S ${ }^{18} \mathrm{O}$ contamination of magmas in the deep Sierra Nevada batholith (abstract), Geol. Soc. Am. Abstr. Prog., 32, 270, 2002.

Lee, C.-T., Q. Yin, R. L. Rudnick, J. T. Chesley, and S. B. Jacobsen, Re-Os isotopic evidence for preMiocene delamination of lithospheric mantle beneath the Sierra Nevada, California, Science, 289, 1912-1916, 2000

Lee, C. T., R. L. Rudnick, and G. H. Brinhall Jr., Deep lithospheric dynamics beneath the Sierra Nevada during the Mesozoic and Cenozoic as inferred from xenolith petrology, Geochem. Geophys., 2, Paper number 2001GC000152, 2001

Leech, M. L., Arrested orogenic development: Ecogitization, delamination, and tectonic collapse, Earth Planet. Sci. Lett., 185, 149-159, 2001.
Li, Y.-G., T. L. Henyey, and L. T. Silver, Aspects of the crustal structure of the western Mojave Desert, California, from seismic reflection and gravity data J. Geophys. Res., 97, 8805-8816, 1992.

Mack, S., J. B. Saleeby, and J. E. Farrell, Origin and emplacement of the Academy pluton, Fresno County, California, Geol. Soc. Am. Bull., Part 2 90, 633-694, 1979

Malin, P. E., E. D. Goodman, T. L. Henyey, Y.-G. Li, D. A. Okaya, and J. B. Saleeby, Significance of seismic reflections beneath a tilted exposure of deep continental crust, Tehachapi Mountains, California, J. Geophys. Res., 100, 2069-2087, 1995.

Manley, C. R., A. F. Glazner, and G. L. Farmer, Timing of volcanism in the Sierra Nevada of California: Evidence for Pliocene delamination of the batholithic root?, Geology, 28, 811-814, 2000

Melbourne, T., and D. Helmberger, Mantle control of plate boundary deformation, Geophys. Res. Lett., $28,4003-4006,2001$

Menzies, M. A., W. P. Leeman, and C. J. Hawkesworth, Isotope geochemistry of Cenozoic volcanic rock reveals heterogeneity mantle below western U.S.A., Nature, 303, 205-209, 1983

Miller, D. M., T. H. Nilsen, and W. L. Bilodeau, Late Cretaceous to early Eocene geologic evolution of the U.S. Cordillera, in The Geology of North America, vol. G-3, The Cordilleran Orogen: Conterminous U.S., edited by B. C. Burchfiel, P. W. Lipman, and M. L. Zoback, pp. 205-260, Geol. Soc. of Am., Boulder, Colo., 1992.

Miller, J. S., A. F. Glazner, G. L. Farmer, I. B. Suayah, and L. A. Keith, A Sr, Nd, and $\mathrm{Pb}$ isotopic study of mantle domains and crustal structure from Miocene volcanic rocks in the Mojave Desert, California Geol. Soc. Am. Bull., 112, 1264-1279, 2000.

Miller, K. C., and W. D. Mooney, Crustal structure and composition of the southern Foothills Metamorphic Belt, Sierra Nevada, California, from seismic data, J. Geophys. Res., 99, 6865-6880, 1994.

Moore, J. G., The quartz diorite boundary line in the western United States, J. Geol., 67, 197-210, 1959

Mukhopadhyay, B., and W. I. Manton, Upper mantle fragments from beneath the Sierra Nevada batholith: Partial fusion, fractional crystallization and metasomatism in a subduction-related ancient lithosphere, J. Petrol., 35, 1418-1450, 1994.

Nadin, E. S., and J. B. Saleeby, Relationships between the Kern Canyon fault (KCF) and the Proto-Kern Canyon fault (PKCF), southern Sierra Nevada, CA (abstract), Eos Trans. $A G U, 82(47)$, Fall Meet Suppl., Abstract T32B-0902, 2001

Oliver, H. W., and S. L. Robbins, Bouguer gravity map of the California Fresno sheet, scale 1:250,000, Calif. Div. of Mines and Geol., Sacramento, Calif., 1982.

O'Reilly, S. Y., W. L. Griffin, Y. H. Poudjom Djomani, and P. Morgan, Are lithospheres forever? Tracking changes in subcontinental lithospheric mantle through time, GSA Today, 11, 4-10, 2001.

Park, S. K., B. Hirasuna, G. R. Jiracek, and C. Kinn, Magnetotelluric evidence of lithospheric mantle thinning beneath the southern Sierra Nevada, J Geophys. Res., 101, 16,241-16,255, 1996.

Pickett, D. A., and J. B. Saleeby, Thermobarometric constraints on the depth of the exposure and conditions of plutonism and metamorphism at deep levels of the Sierra Nevada batholith, Tehachapi Mountains, California, J. Geophys. Res., 98, 609-629, 1993.

Pickett, D. A., and J. B. Saleeby, $\mathrm{Nd}, \mathrm{Sr}$, and $\mathrm{Pb}$ isotopic characteristics of Cretaceous intrusive rocks from deep levels of the Sierra Nevada batholith, Tehachapi Mountains, California, Contrib. Mineral. Petrol., 118, 198-205, 1994.

Rapp, R. P., and E. B. Watson, Dehydration melting of metabasalts at 8-32 kbar: Implications of continental growth and crust-mantle recycling, J. Petrol., 35, $891-931,1995$.

Ross, D. C., The metamorphic and plutonic rocks of the southernmost Sierra Nevada, California, and their tectonic framework, U.S. Geol. Surv. Prof. Pap., 1381,159 pp., 1989.

Ruppert, S., M. M. Fliedner, and G. Zandt, Thin crust and active upper mantle beneath the southern Sierra Nevada in the western United States, Tectonophy sics, 286, 237-252, 1998.

Saleeby, J. B., Ocean floor accretion and volcanoplutonic arc evolution of the Mesozoic Sierra Nevada, California, in Rubey Volume of the Geotectonic Development of California, edited by W. G. Ernst, pp. 132 - 181, Prentice-Hall, Old Tappan, N. J., 1981.

Saleeby, J. B., Progress in tectonic and petrogenetic studies in an exposed cross-section of young $(\sim 100 \mathrm{Ma})$ continental crust, southern Sierra Nevada, California, in Exposed Cross Sections of the Continental Crust, edited by M. H. Salisbury, pp. 137-158, D. Reidel, Norwell, Mass., 1990.

Saleeby, J. B., On some aspects of the geology of the Sierra Nevada, Geol. Soc. Am. Spec. Pap., 38, $17-$ 184, 1999.

Saleeby, J. B., Segmentation of the Laramide slab-evidence from the southern Sierra Nevada region, Geol. Soc. Am. Bull., 115, 655-668, 2003.

Saleeby, J. B., and Z. A. Foster, Topographic response to mantle lithosphere removal in the southwest Sierra Nevada, California, Geology, in press, 2003.

Saleeby, J. B., and W. D. Sharp, Chronology of the structural and petrologic development of the southwest Sierra Nevada Foothills, California, Geol. Soc. Am. Bull., Part 2, 91, 1416-1535, 1980.

Saleeby, J. B., and H. Williams, Possible origin for California Great Valley gravity-magnetic anomalie (abstract), Eos Trans. AGU, 59(12), 1189, 1978.

Saleeby, J. B., D. B. Sams, and R. W. Kistler, U/Pb zircon, strontium, and oxygen isotopic and geochronological study of the southernmost Sierra Nevada batholith, California, J. Geophys. Res. $92,10,443-10,446,1987$

Saleeby, J. B., R. W. Kistler, S. Longiaru, J. G. Moore, and W. J. Nokleberg, Middle Cretaceous silicic metavolcanic rocks in the Kings Canyon area, central Sierra Nevada, California, Geol. Soc. Am. Mem., 174, $251-270,1990$

Saltus, R. W., and A. H. Lachenbruch, Thermal evolution of the Sierra Nevada: Tectonic implications of new heat flow data, Tectonics, 10, 325-344, 1991

Schmidt, M. W., and S. Poli, Experimentally based water budgets for dehydrating slabs and consequences for arc magma generation, Earth Planet Sci. Lett., 163, 361-379, 1998.

Sharry, J., The geology of the western Tehachapi mountains, California, Ph.D. thesis, 215 p., Mass. Inst. of Technol., Cambridge, 1981.

Silver, L. T., and J. A. Nourse, The Rand Mountains thrust complex in comparison with the Vincent Thrust-Pelona schist relationship, southern California (abstract), Geol. Soc. Am. Abstr. Prog., 18, 185 1986

Sisson, T. W., T. L. Grove, and D. S. Coleman, Hornblende gabbro sill complex at Onion Valley, California, and a mixing origin for the Sierra Nevada batholith, Contrib. Mineral. Petrol., 126, 81-108, 1996

Stern, T., P. C. Bateman, B. A. Morgan, M. F. Newell, and $\mathrm{D}$. L. Peck, Isotopic U-Pb ages of zircon from the granitoids of the central Sierra Nevada, California, U.S. Geol. Surv. Prof. Pap., 1185, 17 pp., 1981.

Tullis, J., and R. A. Yund, Experimental deformation of dry Westerly granite, J. Geophys. Res., 82, $5705-$ 5718, 1977

Ulmer, P., Partial melting in the mantle wedge: The role of $\mathrm{H}_{2} \mathrm{O}$ in the genesis of mantle-derived "arcrelated" magmas, Phys. Earth Planet. Inter., 127, $215-232,2001$

Van Kooten, G., $\mathrm{Pb}$ and $\mathrm{Sr}$ systematics of ultrapotassic and basaltic rocks from the central Sierra Nevada, California, Contrib. Mineral. Petrol., 76, 378-385, 1981

Vielzeuf, D., and M. W. Schmidt, Melting relations in hydrous systems revisited: Application to metapelites, metagreywackes and metabasalts, Contrib. Mineral. Petrol., 141, 251-267, 2001. 
Wernicke, B., Cenozoic extensional tectonics of the U.S. Cordillera, in The Geology of North America, vol. G-3, The Cordilleran Orogen: Conterminous U.S., edited by B. C. Burchfiel, P. W. Lipman, and M. L. Zoback, pp. 553-582, Geol. Soc. of Am., Boulder, Colo., 1992.

Wernicke, B., and J. K. Snow, Cenozoic tectonism in the central basin and range: Motion of the Sierran-Great Valley Block, Int. Geol. Rev., 300, 403-410, 1998.

Wernicke, B., G. J. Axen, and J. K. Snow, Basin and range extensional tectonics at the latitude of Las Vegas, Nevada, Geol. Soc. Am. Bull., 100, $1738-$ 1757, 1988.

Wernicke, B., et al., Origin of high mountains in the continents: The southern Sierra Nevada, Science, $271,190-193,1996$

Wolf, M. B., and P. J. Wyllie, Garnet growth during amphibolite anatexis: Implications of a garnetiferous restite, J. Geol., 101, 357-373, 1993.

Wolf, M. B., and P. J. Wyllie, Dehydration-melting of amphibolite at 10 kbar: The effects of temperature and time, Contrib. Mineral. Petrol., 115, 369-383, 1994.
Wolf, M. B., and P. J. Wyllie, Liquid segregation parameters from amphibolite dehydration melting experiments, J. Geophys. Res., 100, 15,61115,621, 1995.

Wong, I. G., and W. U. Savage, Deep intraplate seismicity in the western Sierra Nevada, central California, Bull. Seismol. Soc. Am., 73, 797-812, 1983.

Wood, D. J., and J. B. Saleeby, Late Cretaceous-Paleocene extensional collapse and disaggregation of the southernmost Sierra Nevada batholith, Int. Geol. Rev., 39, 973-1009, 1998.

Wyllie, P. J., The Dynamic Earth, 416 pp., John Wiley, Hoboken, N. J., 1971.

Zandt, G., The southern Sierra Nevada drip and the mantle wind direction beneath the southwestern United States, Int. Geol. Rev., 45, 213-224, 2003.

Zandt, G., and C. R. Carrigan, Small-scale convective instability and upper mantle viscosity under California, Science, 261, 460-463, 1993.

Zeng, L., C.-T. Lee, and J. Saleeby, Nd-Sr-Os systematics of mantle xenoliths from the Sierra Nevad batholith: Structural and geochemical evolution of a subcontinental lithospheric mantle (abstract), GSA Abstr. Prog., 33, A-396, 2001a.

Zeng, L., J. B. Saleeby, and M. N. Ducea, Limitation on mid-crustal assimilation in the Sierra Nevada batholith (SNB), California (abstract), Eos Trans. $A G U, 82(47)$, Fall Meet. Suppl., Abstract V32E1023, 2001b

Zhao, D., Seismological structure of subduction zones and its implications for arc magmatism and dynamics, Phys. Earth Planet. Inter., 127, $197-$ 214, 2001.

D. Clemens-Knott, Department of Geological Sciences, California State University, Fullerton, CA 92834, USA. (dclemensknott@exchange.fullerton.edu) M. Ducea, Department of Geosciences, University of Arizona, 1040 East Fourth Street, Tucson, AZ 85721 , USA. (ducea@geo.arizona.edu)

J. Saleeby, Division of Geological and Planetary Sciences, California Institute of Technology, Mail Stop 100-23, Pasadena, CA 91125, USA. (jason@gps. caltech.edu) 